\title{
Establishment and characterization of gemcitabine-resistant human cholangiocarcinoma cell lines with multidrug resistance and enhanced invasiveness
}

\author{
WAREEPORN WATTANAWONGDON ${ }^{1,7,8}$, CHARIYA HAHNVAJANAWONG ${ }^{1,7,8}$, NISANA NAMWAT ${ }^{2}$, \\ SIRIMAS KANCHANAWAT ${ }^{3}$, THIDARUT BOONMARS ${ }^{4}$, PATCHAREE JEARANAIKOON ${ }^{6}$, \\ CHANWIT LEELAYUWAT ${ }^{6}$, ANCHALEE TECHASEN ${ }^{6}$ and WUNCHANA SEUBWAI ${ }^{5}$
}

\begin{abstract}
Departments of ${ }^{1}$ Microbiology, ${ }^{2}$ Biochemistry, ${ }^{3}$ Pharmacology, ${ }^{4}$ Parasitology and ${ }^{5}$ Forensic Medicine, Faculty of Medicine,
${ }^{6}$ Center for Research and Development of Medical Diagnostic Laboratories, Faculty of Associated Medical Sciences,

${ }^{7}$ Center of Excellence for Innovation in Chemistry, and ${ }^{8}$ Liver Fluke and Cholangiocarcinoma Research Center, Faculty of Medicine, Khon Kaen University, Khon Kaen 40002, Thailand
\end{abstract}

Received March 17, 2015; Accepted May 4, 2015

DOI: 10.3892/ijo.2015.3019

\begin{abstract}
To establish and characterize the gemcitabineresistant cholangiocarcinoma (CCA) cell lines, CCA KKU-M139 and KKU-M214 cell lines were exposed stepwisely to increasing gemcitabine (GEM). The resultant drug-resistant cell lines, KKU-M139/GEM and KKU-M214/ GEM, retained the resistant phenotype in drug-free medium at least for 2 months. Sulforhodamine B assay demonstrated that KKU-M139/GEM and KKU-M214/GEM were 25.88- and 62.31-fold more resistant to gemcitabine than their parental cells. Both gemcitabine-resistant cell lines were crossresistant to 5-fluorouracil (5-FU), doxorubicin and paclitaxel indicating their multidrug-resistant nature. Using reverse transcriptase-polymerase chain reaction (RT-PCR), real-time PCR and western blot analyses, gemcitabine-resistant cells showed upregulation of RRMI and downregulation of hENTI and $d C K$. In relation to multidrug resistance, these cell lines showed upregulation of multidrug resistance protein 1 (MRP1) leading to an increase of drug efflux. Using cell adhesion and Boyden chamber transwell assays, these cell lines also showed higher cell adhesion, migration and invasion capabilities via the activations of protein kinase $\mathrm{C}$ (PKC), focal adhesion kinase (FAK), extracellular signal-regulated kinase-1/2 (ERK1/2) and nuclear factor $-\kappa \mathrm{B}(\mathrm{NF}-\kappa \mathrm{B})$. Higher activity of matrix metalloproteinase-9 (MMP-9) and urokinase plasminogen activator (uPA) was also observed by a gelatin zymography assay and a casein-plasminogen zymography assay. Flow cytometry analysis indicated the $\mathrm{G} 2 / \mathrm{M}$ arrest regulated by
\end{abstract}

Correspondence to: Dr Chariya Hahnvajanawong, Department of Microbiology, Faculty of Medicine, Khon Kaen University, Khon Kaen 40002, Thailand

E-mail: hchari@kku.ac.th

Key words: cholangiocarcinoma, drug-resistant cell line, gemcitabine, multidrug resistance, evasion apoptosis, invasiveness downregulation of cyclin B1 and cyclin-dependent kinase 1 (Cdk1) resulted in an extended population doubling time. Using Annexin V/propidium iodide staining, evasion of apoptosis via an intrinsic pathway was observed in both cell lines in association with upregulation of $\mathrm{Bcl}-2$ and downregulation of Bax. Interestingly, Fas was additionally downregulated in KKU-M214/GEM supporting the view of its higher GEM resistant characteristics. These findings indicate that long-term exposure of CCA cell lines to gemcitabine induce not only multidrug resistance but also enhance their invasiveness.

\section{Introduction}

Cholangiocarcinoma (CCA) is a cancer originating from the biliary epithelial cells. Its incidence and mortality rate are increasing worldwide (1). Surgical resection of the tumor is the most effective treatment, but only $25 \%$ of patients are resectable at presentation (2). Unresectable CCA patients are recommended for chemotherapy, using either gemcitabine alone or gemcitabine-based regimens (3). Unfortunately, the response rate and median survival time of gemcitabine treatment are only $17.5-30 \%$ over 7.6-14 months (4). The combinations of gemcitabine and cisplatin or oxaliplatin give a response rate of $\sim 35 \%$, and median survival times of 11-15 months (4). A major problem of chemotherapy for human carcinoma, including CCA, is the development of chemoresistance, especially multidrug resistance (MDR) (5).

Gemcitabine (2', 2'-difluorodeoxycytidine, $\mathrm{dFdC}$ ) is a deoxycytidine analogue that has been used widely in the treatment of various solid tumors including CCA $(6,7)$. The expression level of human equilibrative nucleoside transporter 1 (hENT1), the major gemcitabine transporter in human cancer cells, has been reported to correlate with sensitivity to gemcitabine (8). Inside the cell, gemcitabine is phosphorylated by the rate-limiting enzyme deoxycytidine kinase (dCK) to its monophosphate form (dFdCMP) and subsequential to its di- and triphosphate forms (dFdCTP) (9). The incorporation of an active metabolite, $\mathrm{dFdCTP}$, into the DNA or RNA strand, causes chain termina- 
tion, leading to apoptosis (6). Ribonucleotide reductase (RR) is mainly responsible for the conversion of ribonucleoside diphosphate to deoxyribonucleoside diphosphate, which is essential for DNA synthesis. dFdCDP is an inhibitor of RR, thereby causing a decrease in dNTP pools and decrease feedback inhibition of $\mathrm{dCK}$, leading to increase phosphorylation of gemcitabine (10). RR consists of two subunits, RRM1 and RRM2 (10). Overexpression of RRM1 was reported to associate with gemcitabine resistance in non-small cell lung cancer cell lines (11). Gemcitabine kills cancer cells by triggering apoptosis through both intrinsic and extrinsic pathways and the defective apoptotic pathway is considered to be associated with resistance to a wide range of chemotherapeutic drugs of cancer cells $(12,13)$. In the mitochondrial (intrinsic) apoptosis pathway, the Bcl-2 family proteins of both anti-apoptotic proteins (i.e., Bcl-2) and pro-apoptotic proteins (i.e., Bax) play a critical role (14). In the death receptor (extrinsic) apoptosis pathway, the Fas (CD95) system plays a crucial role (12). Increased expression of Bcl-2 protein while decreased expression of Bax and Fas proteins have been reported in chemotherapeutic drug-resistant cancers $(12,15)$.

The mechanism of gemcitabine resistance is well characterized in pancreatic cancer cells, it involves alteration of gemcitabine metabolism, decreased intracellular drug accumulation, inhibition of apoptosis pathways and aberrant activity in signaling pathways that modulate the cell cycle and apoptosis (16).

The mechanism of gemcitabine resistance in CCA is not studied well and the available information is still limited (17). Therefore, better understanding of gemcitabine resistance mechanisms would allow us to improve therapeutic strategies for CCA. In this study, we established high and stable gemcitabine-resistant CCA cell lines (KKU-M139/GEM and KKU-M214/GEM) and investigated gene expressions associated with gemcitabine transport, metabolism and characterized the biological properties compared with their parental cells. Moreover, the molecular mechanisms and signaling pathways of both cell lines were also evaluated.

\section{Materials and methods}

Cell culture. Two human intrahepatic CCA cell lines, KKU-M139 and KKU-M214 were established in the Liver Fluke and Cholangiocarcinoma Research Center, Khon Kaen University, Thailand (18-20). Both cell types were cultured in RPMI-1640 medium (Gibco BRL, Grand Island, NY, USA) containing $10 \%$ fetal bovine serum, $100 \mathrm{U} / \mathrm{ml}$ of penicillin and $100 \mathrm{mg} / \mathrm{ml}$ streptomycin (Gibco BRL) at $37^{\circ} \mathrm{C}$ in $5 \% \mathrm{CO}_{2}$ humidified atmosphere.

Cytotoxicity assay. The parental CCA cells (KKU-M139 and KKU-M214) and their drug-resistant cells (KKU-M139/GEM and KKU-M214/GEM) were seeded at $1 \times 10^{4}$ cells/well in triplicate into 96-well culture plates (Costar, Cambridge, MA, USA) for 24 h. KKU-M139 and KKU-M139/GEM were treated with 0.025-16 $\mu \mathrm{M}$ of gemcitabine (Lilly Pharmaceuticals, Fegersheim, France), 0.5-64 $\mu \mathrm{M}$ of 5-FU (Boryung Pharm, Seoul, Korea), 0.5-100 $\mu \mathrm{M}$ of doxorubicin (Dabur Pharma Ltd., New Delhi, India), and 0.1-8 $\mu \mathrm{M}$ of paclitaxel (BristolMyers-Squibb Co., Princeton, NJ, USA) while KKU-M214 and KKU-M214/GEM were treated with $0.025-64 \mu \mathrm{M}$ of gemcitabine, $0.5-128 \mu \mathrm{M}$ of 5-FU, 0.05-16 $\mu \mathrm{M}$ of doxorubicin, and $0.01-0.8 \mu \mathrm{M}$ of paclitaxel, in triplicate for $72 \mathrm{~h}$. Cells treated with $0.9 \%$ normal saline was used as the solvent-control cells. Cytotoxicity was determined using the sulforhodamine B (SRB) assay (21). Drug concentrations required to inhibit 50\% cell growth $\left(\mathrm{IC}_{50}\right)$ were calculated from concentration-effect curves after linear regression analysis. The extent of the resistance of drug-resistant cells to chemotherapeutic drugs was determined as the resistance ratio (RR), which is a ratio of the $\mathrm{IC}_{50}$ value of drug-resistant cells to parental cells.

Induction of gemcitabine-resistant CCA cell lines. KKU-M139 and KKU-M214 cell lines were exposed to the graded concentrations of gemcitabine as described previously (22). In brief, cells $\left(1 \times 10^{5}\right)$ were cultured in $25-\mathrm{cm}^{2}$ flasks (SPL Life Sciences, Pocheon, Korea) for $24 \mathrm{~h}$ and then exposed to gemcitabine at a concentration of $1 \mathrm{X} \mathrm{IC}_{50}$ value $(0.41 \mu \mathrm{M}$ for KKU-M139, $0.45 \mu \mathrm{M}$ for KKU-M214) for $72 \mathrm{~h}$. Surviving cells were cultured in drug-free medium to allow cells to attain $80 \%$ confluence. These cells were cultured at this drug concentration until they grew steadily and then the $\mathrm{IC}_{50}$ values of these two CCA cell lines were determined by the SRB assay (21). These surviving cells were then exposed to gemcitabine at 2 -fold increase of $\mathrm{IC}_{50}$ concentration for 6 rounds. Two human gemcitabine-resistant CCA cell lines, KKU-M139/GEM and KKU-M214/GEM were obtained after 14 months of culture. KKU-M139/GEM and KKU-M214/GEM grew steadily under the presence of gemcitabine at 6 and $14 \mu \mathrm{M}$, respectively. Both drug-resistant CCA cell lines were grown in drug-free medium for two weeks then harvested, frozen in the liquid nitrogen, and stored at $-80^{\circ} \mathrm{C}$ until analyzed. These drug-resistant cells were cultured in drug-free medium for 2 weeks before performing the experiments.

Doubling time. Doubling time of both parental and gemcitabineresistant CCA cell lines was determined using the trypan blue dye exclusion test. In brief, cells were plated in triplicate at a density of $1 \times 10^{5}$ cells/well in 6-well plates (SPL Life Sciences) in drug-free medium for 24, 48 and $72 \mathrm{~h}$. At each time-point, cells were harvested, stained with trypan blue and counted on a hemocytometer. Doubling time was calculated using the formula $\left[\left(\mathrm{T}-\mathrm{T}_{0}\right) \times \log 2\right] /\left(\log \mathrm{N}-\log \mathrm{N}_{0}\right)$ where $\mathrm{T}$ is the total time at mid log-phase, $\mathrm{T}_{0}$ is the time zero, $\mathrm{N}$ is the total number of cells at mid log-phase, and $\mathrm{N}_{0}$ is the total number of cells at the day of plating (19).

Cell cycle analysis. Cells were plated at a density of $1 \times 10^{5}$ cells/well in 6-well plates for $24 \mathrm{~h}$. Cells were harvested, washed twice with cold phosphate buffered saline (PBS), fixed overnight in $70 \%$ ethanol at $4^{\circ} \mathrm{C}$, incubated for $30 \mathrm{~min}$ in the dark with RNase A (final concentration $2 \mu \mathrm{g} / \mathrm{ml}$ ) and propidium iodide (PI) (final concentration $2.4 \mu \mathrm{g} / \mathrm{ml}$ ) at room temperature. The cell cycle distribution was examined using a FACScanto $^{\mathrm{TM}}$ II flow cytometer (Becton-Dickinson, San Jose, CA, USA) and the data were analyzed using FACS Diva ${ }^{\mathrm{TM}}$ software (Becton-Dickinson).

Apoptosis assay. Cells ( $1 \times 10^{5}$ cells/well) were plated in triplicate into 6-well plates for $24 \mathrm{~h}$. KKU-M139 and 
Table I. Primer sequences used for real-time PCR.

\begin{tabular}{lllr}
\hline Gene & \multicolumn{1}{c}{ Forward } & \multicolumn{1}{c}{ Reverse } & Refs. \\
\hline$h E N T 1$ & 5'-TGTGCTTCGGGCCCAAGAA-3' & 5'-TTGCCCGGAACAGGAAGGA-3' & $(19)$ \\
$d C K$ & 5'-GATGATGTATGAGAAACCTGAACG-3' & 5'-CCAGTCTTGATAAATTGTCCACTC-3' & $(24)$ \\
$R R M 1$ & 5'-CACATCAGAACACACATACGAC-3' & 5'-GCACTCTCAAAAGGGTATCTCA-3' & $(24)$ \\
GAPDH & 5'-TCATCAGCAATGCCTCCTGCA-3' & 5'-TGGGTGGCAGTGATGGCA-3' & $(19)$ \\
\hline
\end{tabular}

hENT1, human equilibrative nucleoside transporter-1; $d C K$, deoxycytidine kinase; RRM1, ribonucleotide reductase M1; GAPDH, glyceraldehyde-3-phosphate dehydrogenase.

KKU-M139/GEM were then treated with $9 \mu \mathrm{M}$ gemcitabine, whereas KKU-M214 and KKU-M214/GEM were treated with $16 \mu \mathrm{M}$ gemcitabine for $48 \mathrm{~h}$. Apoptotic cells were determined by the Annexin V-FLUOS staining kit (Roche Diagnostic, Mannheim, Germany) according to the manufacturer's instructions. After treatment, floating and adherent cells were collected, washed twice with cold PBS, resuspended in $100 \mu 1$ binding buffer containing $2 \mu \mathrm{l}$ Annexin V-FITC and $2 \mu \mathrm{l}$ PI $(50 \mu \mathrm{g} / \mathrm{ml})$ and incubated at room temperature for $15 \mathrm{~min}$ in the dark. Then, flow cytometric analysis was performed. Data acquisition and analysis were performed using a FACScanto II flow cytometer and the data were analyzed using FACS Diva software.

Cell adhesion assay. Flat-bottom 96-well plates were coated overnight at $37^{\circ} \mathrm{C}$ with $30 \mu \mathrm{g} / \mathrm{well}$ of Matrigel, then washed twice with PBS and blocked at room temperature for $90 \mathrm{~min}$ with $3 \%$ bovine serum albumin (BSA) (Pierce Biotechnology Inc., Rockford, IL, USA) in serum-free medium. Cells $\left(1 \times 10^{4}\right.$ cells/ well) were plated and allowed to adhere for $1 \mathrm{~h}$. The nonadherent cells were removed by washing with PBS and the adherent cells were fixed for $30 \mathrm{~min}$ in $20 \%$ trichloroacetic acid (TCA) (Sigma Chemical Co., St. Louis, MO, USA). The adherent cells were stained with an SRB dye. The cells were counted under a light microscope, the mean value of 5 random low-power fields (x10 magnification) was determined. Data were presented as the percentage of adherent cells to total cells. The experiments were performed in triplicate with three independent experiments.

Cell migration and invasion assays. A cell migration and invasion assay were performed using the modified Boyden chamber system. In brief, cells $\left(1 \times 10^{5}\right.$ cells/well) in serum-free medium were plated onto the upper chamber of Transwell ${ }^{\circledR}$ precoated Matrigel-culture inserts (8- $\mu \mathrm{m}$ pore size polycarbonate membrane filters; Becton-Dickinson). The lower chamber contained RPMI-1640 medium supplemented with 10\% FBS as a chemo-attractant. After incubation for $48 \mathrm{~h}$, cells on the upper surface of the membrane were wiped away. The invaded cells on the undersurface of the membrane were fixed with $20 \%$ TCA, and stained with SRB dye (Sigma Chemical Co.). Cells were counted under a light microscope, and the mean value of 5 randomly selected low-power fields (x20 magnification) was determined. The migration assay was performed similar to the invasion assay without Matrigel coating on the membrane. The experiments were performed in triplicate using two independent experiments.
Zymographic analysis. MMP-9 activity was determined by gelatin zymography (23). Cells ( $1 \times 10^{5}$ cells/well) were plated in 6-well plates in RPMI-1640 medium containing 10\% FBS for $24 \mathrm{~h}$. Cells at $70 \%$ confluence were incubated in serum-free RPMI-1640 medium for $24 \mathrm{~h}$, and the supernatants were collected. The protein concentration of the supernatants was determined by the Coomassie protein assay kit (Pierce Biotechnology). The supernatant protein $(20 \mu \mathrm{g})$ was electrophoresed in $7.5 \%$ polyacrylamide gels containing $0.1 \%$ gelatin and sodium dodecyl sulfate (SDS) under non-reducing conditions. Gels were washed twice at room temperature in 2.5\% Triton X-100 with gentle agitation and subsequently incubated in developing buffer $(50 \mathrm{mM}$ Tris- $\mathrm{HCl}, \mathrm{pH} 8.0$; $5 \mathrm{mM} \mathrm{CaCl}{ }_{2}$ and $0.02 \% \mathrm{NaN}_{3}$ ) at $37^{\circ} \mathrm{C}$ for $20 \mathrm{~h}$. Gels were stained with staining solution $(0.5 \%$ Coomassie brilliant blue, $30 \%$ methanol and $10 \%$ acetic acid) and were destained in the same solution without Coomassie brilliant blue. Gelatinase activity of MMPs appeared as clear bands on blue background. Digestion bands were quantitated using the Scion Image program (Scion Corp., Frederick, MD, USA).

The uPA activity was determined by casein-plasminogen zymography (23). In brief, the supernatant was electrophoresed in $7.5 \%$ polyacrylamide gels containing $2 \%$ casein $(\mathrm{w} / \mathrm{v})$ and $20 \mu \mathrm{g} / \mathrm{ml}$ plasminogen, and then processed as described in the gelatin zymography.

$R N A$ extraction, reverse transcription $(R T)$ and real-time polymerase chain reaction $(P C R)$. Total RNA was extracted from parental and drug-resistant cells using TRIzol ${ }^{\circledR}$ reagent (Invitrogen, Carlsbad, CA, USA) according to the manufacturer's instructions. The first-strand cDNA was synthesized from RNA by reverse transcription at $42^{\circ} \mathrm{C}$ for $60 \mathrm{~min}$ in a 20- $\mu \mathrm{l}$ reaction mixture containing $3 \mu \mathrm{g}$ of total RNA, $0.5 \mu \mathrm{g}$ of oligo $(\mathrm{dT})_{15}$ primer (Amersham Pharmacia Biotechnology Inc., Piscataway, NJ, USA), 20 U RNasin ribonuclease inhibitor and $20 \mathrm{U}$ of Moloney murine leukemia virus (MMLV) reverse transcriptase (Fermentas, Ontario, Canada) in $5 \mathrm{X}$ polymerase chain reaction (PCR) buffer, $10 \mathrm{mM}$ dNTPs and $3 \mathrm{mM} \mathrm{MgCl}_{2}$.

Real-time PCR was conducted according to the manufacturer's instruction in a final volume of $25 \mu$ l containing 2X SYBR Green PCR Master Mix (Roche Applied Science, Mannheim, Germany), cDNA template and 5 pmol of each primer using a LightCycler ${ }^{\circledR} 480$ Instrument (Idaho Technology, Inc., UT, USA). The PCR primers for $h E N T 1$, $d C K, R R M 1$ and glyceraldehyde-3-phosphate dehydrogenase $(G A P D H)$ (Integrated DNA Technologies, Coralville, IA, 
Table II. Primary antibody used in western blot analysis.

\begin{tabular}{|c|c|c|c|c|}
\hline Target & Type & Host species/targeted species & Dilution & Second antibody \\
\hline Cyclin B1 & Polyclonal & Rabbit anti-human & $1: 400$ & Goat anti-rabbit \\
\hline Cdk1 & Polyclonal & Rabbit anti-human & $1: 400$ & Goat anti-rabbit \\
\hline $\mathrm{p} 21$ & Polyclonal & Rabbit anti-human & $1: 400$ & Goat anti-rabbit \\
\hline Bcl-2 & Polyclonal & Rabbit anti-human & $1: 200$ & Goat anti-rabbit \\
\hline Bax & Polyclonal & Rabbit anti-human & $1: 200$ & Goat anti-rabbit \\
\hline FAK & Polyclonal & Rabbit anti-human & $1: 400$ & Goat anti-rabbit \\
\hline p-FAK & Polyclonal & Rabbit anti-human & $1: 200$ & Goat anti-rabbit \\
\hline MMP-9 & Monoclonal & Mouse anti-human & $1: 1,000$ & Goat anti-mouse \\
\hline $\mathrm{NF}-\kappa \mathrm{B} / \mathrm{p} 65$ & Polyclonal & Rabbit anti-human & $1: 500$ & Goat anti-rabbit \\
\hline $\mathrm{PKC}$ & Polyclonal & Rabbit anti-human & $1: 500$ & Goat anti-rabbit \\
\hline Fas & Polyclonal & Rabbit anti-human & $1: 400$ & Goat anti-rabbit \\
\hline FADD & Polyclonal & Rabbit anti-human & $1: 400$ & Goat anti-rabbit \\
\hline MRP1 & Polyclonal & Rabbit anti-human & $1: 200$ & Goat anti-rabbit \\
\hline p53 & Monoclonal & Mouse anti-human & $1: 1,000$ & Goat anti-mouse \\
\hline ERK1/2 & Polyclonal & Rabbit anti-human & $1: 400$ & Goat anti-rabbit \\
\hline p-ERK $1 / 2$ & Polyclonal & Rabbit anti-human & $1: 400$ & Goat anti-rabbit \\
\hline$\beta$-actin & Monoclonal & Mouse anti-human & $1: 3,000$ & Goat anti-mouse \\
\hline Histone H1 & Monoclonal & Mouse anti-human & $1: 500$ & Goat anti-mouse \\
\hline
\end{tabular}

Cdk1, cyclin-dependent kinase 1; p21, protein 21; Bcl-2, B-cell lymphoma protein 2; Bax, Bcl-2 associated X protein; FAK, focal adhesion

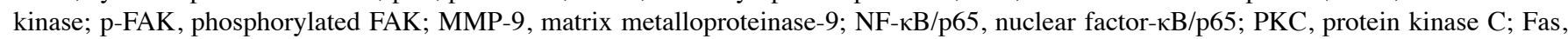
fatty acid synthetase; FADD, Fas-associated death domain; MRP1, multidrug resistance-associated protein 1; p53, protein 53; ERK1/2, extracellular signal-regulated kinase-1/2; p-ERK1/2, phosphorylated ERK1/2.

USA) are given in Table I (19,24). Real-time PCR started with a denaturation step at $95^{\circ} \mathrm{C}$ for $10 \mathrm{~min}$, followed by 45 cycles of denaturation at $95^{\circ} \mathrm{C}$ for $15 \mathrm{sec}$, annealing at $60^{\circ} \mathrm{C}$ for $30 \mathrm{sec}$ and extension at $72^{\circ} \mathrm{C}$ for $1 \mathrm{~min}$, then final extension at $72^{\circ} \mathrm{C}$ for $10 \mathrm{~min}$. To verify amplification products, a melting curve was constructed from 60 to $99^{\circ} \mathrm{C}$. The comparative $\mathrm{Ct}$ method was used to calculate a relative expression of target mRNA as described previously (25). The mRNA expressions of target genes were normalized to the GAPDH gene and given as fold change in gene expression level between parental and drugresistant cells. All data were analyzed using LightCycler 480 software, version 1.5 (Roche Applied Science).

Preparation of total cell, cytosol or nuclear lysates or membrane proteins. To prepare total cell lysate, cells were rinsed twice with PBS and lysed by vigorous shaking at $4^{\circ} \mathrm{C}$ for 20 min with cold RIPA buffer (50 mM Tris-HCl, $\mathrm{pH} 7.5$, $0.5 \%$ Nonidet P-40, $150 \mathrm{mM} \mathrm{NaCl}, 1 \mathrm{mM}$ dithiothreitol, $1 \mathrm{mM}$ EDTA, $0.1 \%$ sodium dodesyl sulfate, $0.5 \%$ deoxycholate) containing protease inhibitors cocktail (Pierce Biotechnology) and phosphatase inhibitors cocktail (Pierce Biotechnology). Cell lysates were centrifuged at $13,000 \mathrm{~g}$ at $4^{\circ} \mathrm{C}$ for $30 \mathrm{~min}$, and the supernatants were collected. To prepare cytosol lysate, cells were lysed with ice-cold buffer A (10 mM HEPES, $0.1 \mathrm{mM}$ EDTA, $10 \mathrm{mM} \mathrm{KC1,0.2 \%} \mathrm{NP40,} 1.5 \mathrm{mM} \mathrm{MgCl}_{2}$, $1 \mathrm{mM}$ DTT, and $0.5 \mathrm{mM}$ phenylmethylsulfonyl fluoride), followed by vortexing and centrifugation at $13,000 \mathrm{~g}$ at $4^{\circ} \mathrm{C}$ for
$30 \mathrm{~min}$. Supernatants were collected as cytosolic fraction. The nuclear pellets were extracted with ice-cold buffer B $(20 \mathrm{mM}$ HEPES, $1.5 \mathrm{mM} \mathrm{MgCl}_{2}$, 25\% glycerol, $0.1 \mathrm{mM}$ EDTA, $1 \mathrm{mM}$ DTT, $420 \mathrm{mM} \mathrm{NaCl}$, and $0.5 \mathrm{mM}$ phenylmethylsulfonyl fluoride). Nuclear proteins in the supernatant were collected after centrifugation at $13,000 \mathrm{~g}$ for $30 \mathrm{~min}$ at $4^{\circ} \mathrm{C}$. The final pellets were resuspended in buffer $\mathrm{C}$ (20 mM HEPES pH 7.9, $1.5 \mathrm{mM} \mathrm{MgCl}_{2}, 10 \mathrm{mM} \mathrm{KCl}, 1 \mathrm{mM}$ EDTA, $250 \mathrm{mM}$ sucrose, $10 \%$ glycerol, $0.1 \%$ sodium deoxycholate, $0.5 \%$ NP-40, $1 \mathrm{mM}$ sodium orthovanadate) and membrane proteins in the supernatant were collected after centrifugation at $13,000 \mathrm{~g}$ at $4^{\circ} \mathrm{C}$ for $30 \mathrm{~min}$. All lysates were stored at $-80^{\circ} \mathrm{C}$ until use. Protein concentration was determined using the Coomassie protein assay kit (Pierce Biotechnology).

Western blotting. Equal amounts of proteins were separated in a $7.5 \%$ or $12 \%$ SDS-polyacrylamide gel electrophoresis and electroblotted onto nitrocellulose membranes (Millipore, Billerica, MA, USA). After blocking with Tris-buffered saline containing $0.1 \%$ Tween-20 and 5\% skimmed milk at room temperature for $1 \mathrm{~h}$, the blots were incubated at $4^{\circ} \mathrm{C}$ overnight with primary antibodies against Cyclin B1, Cdk1, p21, Bcl-2, Bax, FAK, p-FAK, MMP-9, NF-кB/p65, PKC, Fas, FADD and MRP1 (Santa Cruz Biotechnology, Santa Cruz, CA, USA) or p53 (Upstate, CA, USA) or ERK1/2, p-ERK1/2 (Cell Signaling Technology Inc., Beverly, MA, USA) or $\beta$-actin (Sigma Chemical Co.) or Histone H1 (Abcam, Cambridge, UK). These 
Table III. IC $_{50}$ values and resistant ratio in parental and gemcitabine-resistant cell lines to various chemotherapeutic drugs.

\begin{tabular}{llccccccc}
\hline & \multicolumn{7}{c}{ IC $_{50}$ value $(\mu \mathrm{M})$} \\
\cline { 2 - 9 } Drugs & KKU-M139 & KKU-M139/GEM & RR & p-value & KKU-M214 & KKU-M214/GEM & RR & p-value \\
\hline Gemcitabine & $0.41 \pm 0.006$ & $10.16 \pm 0.10$ & 25.88 & $<0.001$ & $0.45 \pm 0.006$ & $28.04 \pm 0.68$ & 62.31 & $<0.01$ \\
5-FU & $3.31 \pm 0.08$ & $26.12 \pm 0.17$ & 7.89 & $<0.01$ & $3.76 \pm 0.16$ & $79.73 \pm 2.15$ & 21.20 & $<0.001$ \\
Doxorubicin & $3.59 \pm 0.40$ & $27.69 \pm 0.40$ & 7.71 & $<0.01$ & $0.74 \pm 0.06$ & $13.48 \pm 1.3$ & 18.22 & $<0.05$ \\
Paclitaxel & $0.45 \pm 0.06$ & $3.13 \pm 0.35$ & 6.96 & $<0.05$ & $0.05 \pm 0.006$ & $0.36 \pm 0.04$ & 7.2 & $<0.01$ \\
\hline
\end{tabular}

NS, not significant difference. RR, resistant ratio.

primary antibodies are listed and characterized in Table II. Blots were incubated at room temperature for $1 \mathrm{~h}$ with the horseradish peroxidase-conjugated goat anti-mouse $\mathrm{IgG}$ and goat anti-rabbit IgG antibodies (Santa Cruz Biotechnology), washed, and were visualized by an enhanced chemiluminescence kit (Pierce Biotechnology). Band intensity was visualized and captured using the Imagequant ${ }^{\mathrm{TM}}$ LAS 4000 (GE Healthcare, Piscataway, NY, USA) and analyzed using the Scion Image program. Relative intensity was determined and normalized to $\beta$-actin (total cell, cytosolic and membrane lysates) or Histone H1 (nuclear lysate).

Statistical analysis. Statistical analyses of parental and gemcitabine-resistant cells were performed using Student's t-test, ${ }^{*} \mathrm{p}<0.05$ indicates a significant difference. Comparison between two CCA cell lines were analyzed by Mann-Whitney test, ${ }^{\#} \mathrm{p}<0.05$ indicates a significant difference.

\section{Results}

Establishment of gemcitabine resistance in cholangiocarcinoma cell lines. Gemcitabine-resistantcell lines were established from parental KKU-M139 and KKU-M214 cell lines by exposure to stepwisely increasing concentrations of gemcitabine over a period of 14 months. The increment of gemcitabine concentration was from 0.40 to $12.80 \mu \mathrm{M}$ for KKU-M139 cells, and from 0.45 to $14.40 \mu \mathrm{M}$ for KKU-M214 cells. The established resistant cells were designated as KKU-M139/GEM and KKU-M214/GEM. No apparent morphological differences were observed between parental and gemcitabine-resistant cells. The growth rate of both gemcitabine-resistant cells was slightly slower than that of their parental cells. The population doubling time of parental KKU-M139 and resitant KKU-M139/ GEM cell lines were $17.36 \pm 1.26$ and $20.32 \pm 2.79 \mathrm{~h}$, and that of parental KKU-M214 and resistant KKU-M214/GEM cell lines were $22.68 \pm 2.20$ and $25.21 \pm 1.88 \mathrm{~h}$, respectively.

The sensitivity of the parental and gemcitabine-resistant cells to gemcitabine, 5-FU, doxorubicin and paclitaxel was examined. The $\mathrm{IC}_{50}$ values and the resistance ratios for the gemcitabine-resistant cells and the parental cells are shown in Table III. Both KKU-M139/GEM and KKU-M214/GEM were remarkably resistant to gemcitabine compared with their parental cells. KKU-M214/GEM was more resistant to gemcitabine with resistant ratio (RR) of 62.31 compared with KKU-M139/GEM with RR of 25.88 (Table III). In addition,
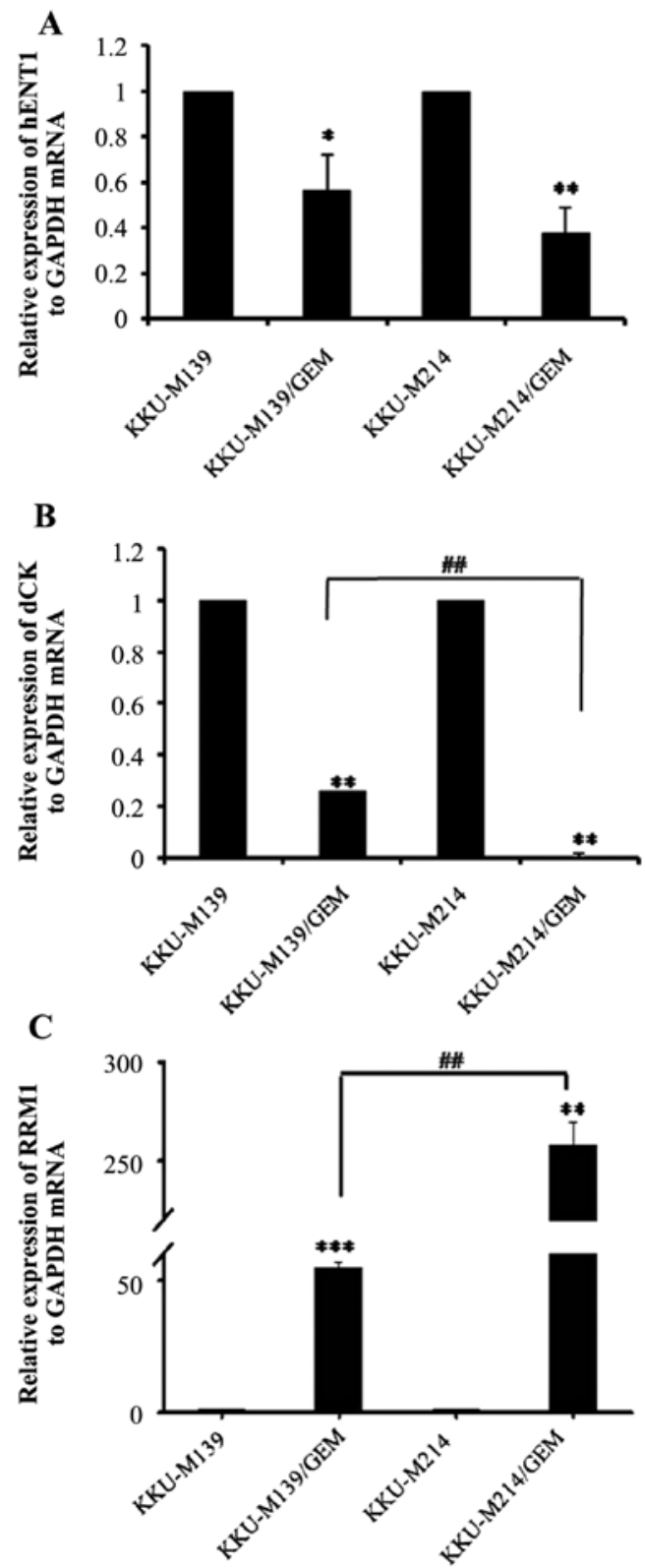

Figure 1. Decreased mRNA expression of (A) $h E N T 1$ and (B) $d C K$ while increased mRNA expression of (C) RRM1 in KKU-M139/GEM and KKU-M214/GEM compared with the parental cells by real-time PCR. $G A P D H$ was amplified as an internal control. Data are expressed as the mean \pm SD of three independent experiments. Statistical analyses of parental and gemcitabine-resistant cells were performed using Student's t-test, ${ }^{*} \mathrm{p}<0.05$, ${ }^{* *} \mathrm{p}<0.01,{ }^{* * *} \mathrm{p}<0.001$ indicate a significant difference. Comparison between two CCA cell lines were analyzed by Mann-Whitney test, ${ }^{\# \#} \mathrm{p}<0.01$ indicates a significant difference. 

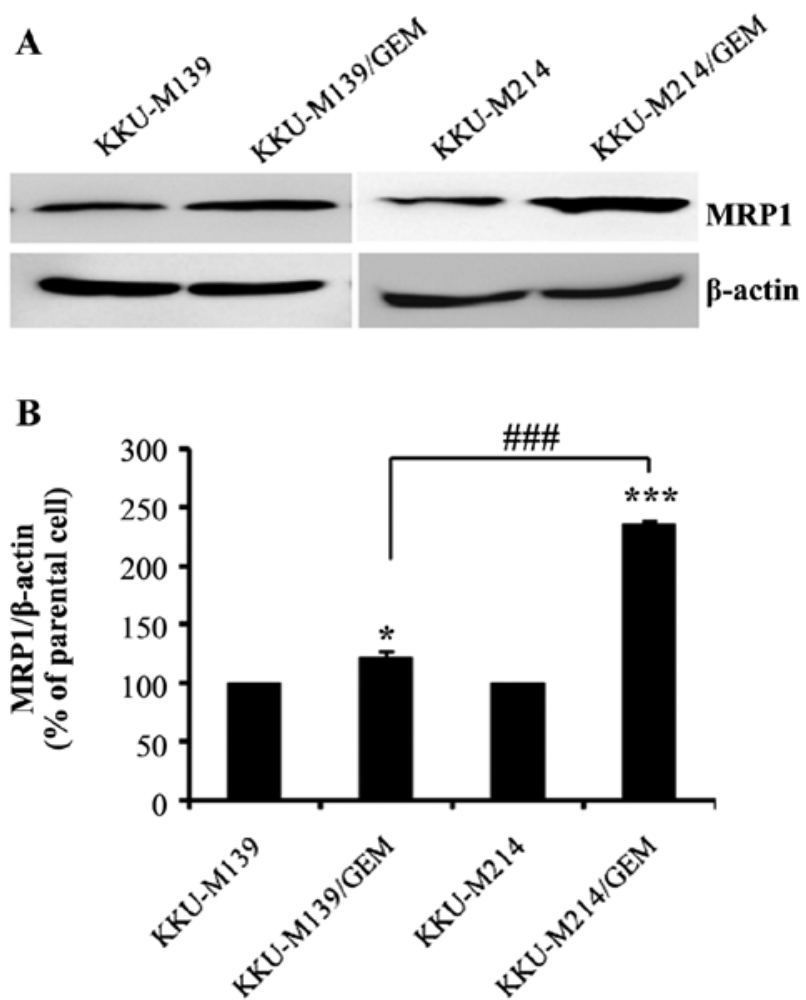

Figure 2. Expression level of MRP1 protein was higher in KKU-M139/GEM and KKU-M214/GEM compared with their parental cells. (A) Western blot analysis for MRP1 protein was performed in KKU-M139, KKU-M139/GEM, KKU-M214, KKU-M214/GEM. (B) The band intensity of MRP1 protein was quantified by densitometry and normalized to $\beta$-actin. Data are expressed as mean \pm SD of three independent experiments. Statistical analyses of parental and gemcitabine-resistant cells were performed using Student's t-test, ${ }^{*} \mathrm{p}<0.05,{ }^{* * *} \mathrm{p}<0.001$ indicate a significant difference. Comparison between two CCA cell lines were analyzed by Mann-Whitney test, ${ }^{\# \#} \mathrm{p}<0.001$ indicates a significant difference.

both resistant cell lines showed cross-resistance against 5-FU, doxorubicin and paclitaxel, suggesting their acquisition of a potential multidrug-resistant (MDR) phenotype. $\mathrm{IC}_{50}$ values of gemcitabine of both resistant cells remained unchanged after sequential passages in gemcitabine-free medium for 2 months with the $\mathrm{IC}_{50}$ value of $10.26 \pm 0.17 \mu \mathrm{M}$ for KKU-M139/GEM, and that of $26.62 \pm 0.16 \mu \mathrm{M}$ for KKU-M214/GEM. Similar stability was also observed after storage of the cells at $-80^{\circ} \mathrm{C}$ for 3 months with the $\mathrm{IC}_{50}$ values of $10.27 \pm 0.04 \mu \mathrm{M}$ for KKU-M139/GEM and that of $27.08 \pm 0.41 \mu \mathrm{M}$ for KKU-M214/GEM.

Alteration of $h E N T 1, d C K$ and RRMI $m R N A$ expression in gemcitabine-resistant CCA cell lines. The expression levels of hENTI, $d C K$ and RRM1 mRNA in the parental and gemcitabine-resistant cells were determined using real-time RT-PCR. The expression levels of $h E N T 1$ and $d C K$ mRNA in both gemcitabine-resistant cell lines were significantly lower than that of their parental cells ( $<<0.05$, Fig. 1). In contrast, the expression levels of RRM1 mRNA in the gemcitabine-resistant cells were significantly higher than that of their respective parental cells ( $p<0.01$, Fig. 1). KKU-M214/GEM showed lower expression levels of $h E N T 1$ and $d C K$ mRNA (p<0.01, Fig. 1B) and significantly higher expression level of RRM1 mRNA (p<0.01, Fig. 1C) than KKU-M139/GEM.

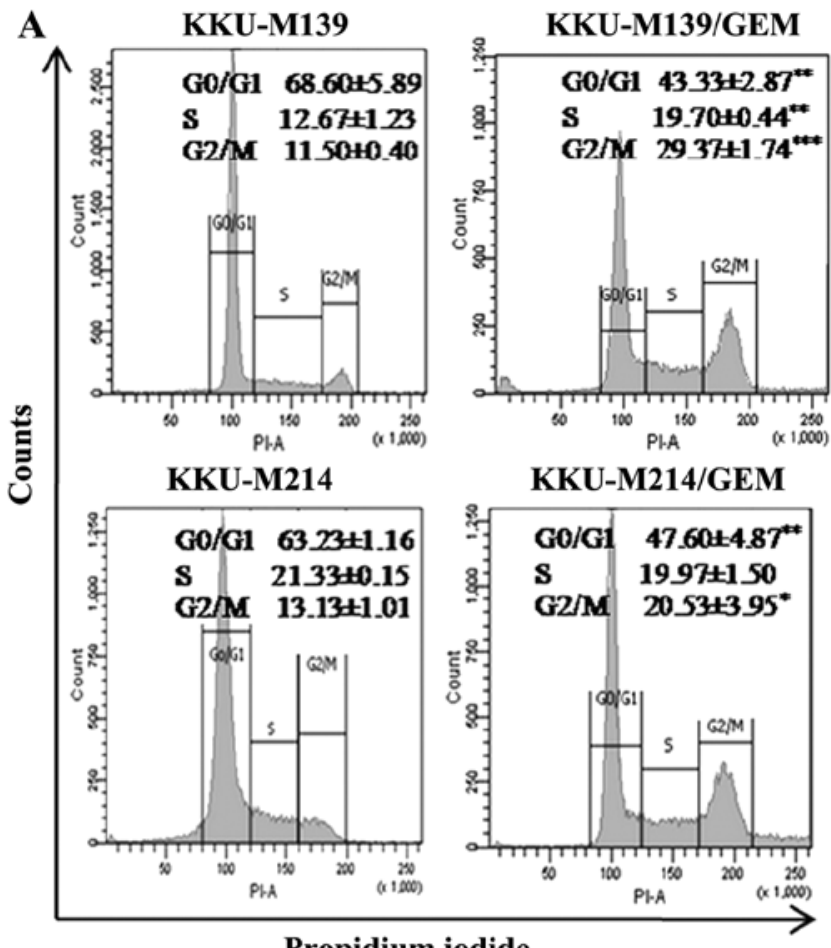

Propidium iodide

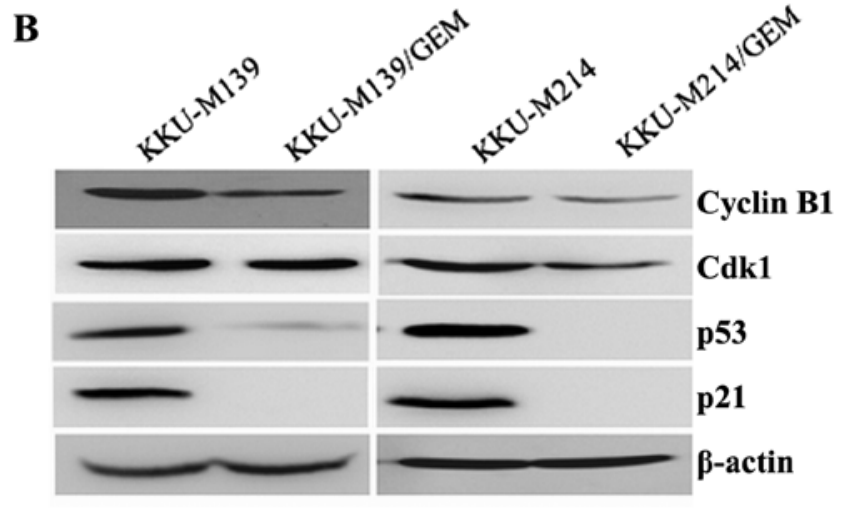

C
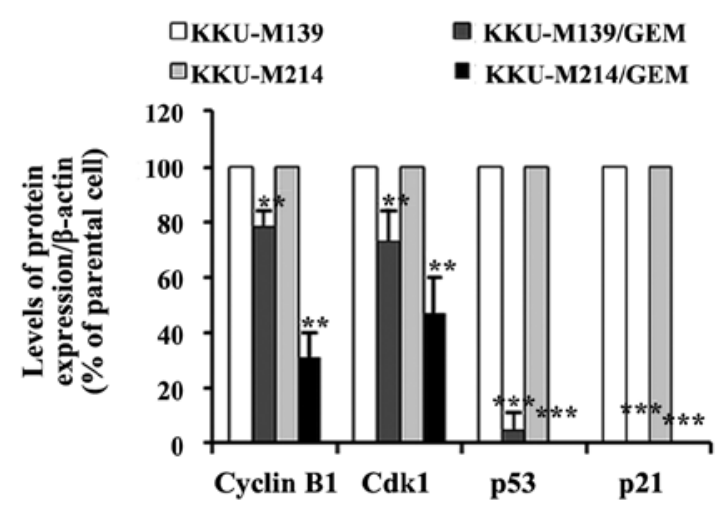

Figure 3. Change in cell cycle distribution and downregulation of G2/M phase-regulated proteins in KKU-M139/GEM and KKU-M214/GEM cells. (A) KKU-M139 and KKU-M139/GEM (top panel) and KKU-M214 and KKU-M214/GEM (bottom panel) were placed onto the 6-well plates in drugfree medium for $24 \mathrm{~h}$ and flow cytometry was performed. (B) Western blot analysis of $\mathrm{G} 2 / \mathrm{M}$ phase regulated protein expression and subsequent densitometry are shown. The densities of cyclin B1, Cdk1, p53 and p21 were decreased in KKU-M139/GEM and KKU-M214/GEM compared with their parental cells. (C) Densitometric scanning of bands after normalization to $\beta$-actin demonstrated cyclin B1, Cdk1, p53 and p21 protein expressions in KKU-M139/GEM and KKU-M214/GEM. All data are expressed as mean \pm SD of three separated experiments. Statistical analyses of parental and gemcitabine-resistant cells were performed using Student's t-test, ${ }^{*} \mathrm{p}<0.05,{ }^{* *} \mathrm{p}<0.01,{ }^{* * *} \mathrm{p}<0.001$ indicate a significant difference. 
A

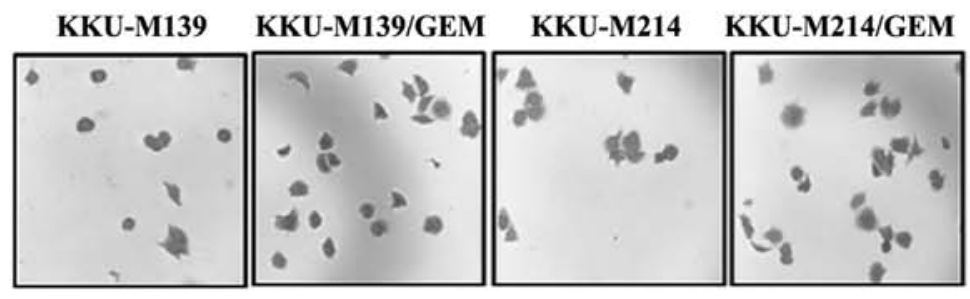

B

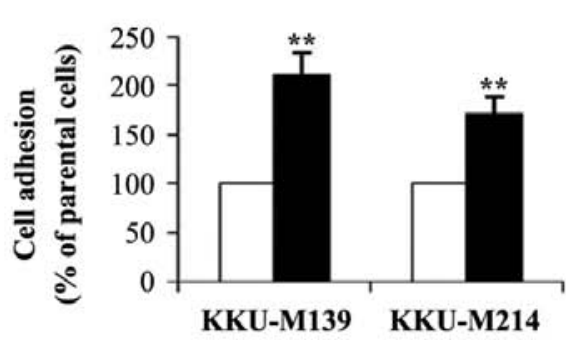

Figure 4. Cell adhesion was increased in KKU-M139/GEM and KKU-M214/GEM cells compared with their parental cells. (A) Representative images of SRBstained adhesive cells determined by adhesion assay. (B) Percentage (\%) of cell adhesion compared to the parental cells. Statistical analyses of parental and gemcitabine-resistant cells were performed using Student's t-test, ${ }^{* *} \mathrm{p}<0.01$ indicates a significant difference.

MRPI protein expression is increased in gemcitabineresistant CCA cell lines. The MRP1 protein expression in parental and gemcitabine-resistant cell lines were evaluated using western blot analysis. Compared to the parental cells, the MRP1 protein expression was significantly higher in gemcitabine-resistant cells ( $\mathrm{p}<0.05$, Fig. 2).

Change in cell cycle distribution in gemcitabine-resistant CCA cell lines. Cell cycle distributions in parental and gemcitabineresistant cells were determined using flow cytometry. The proportion of the cells in S and G2/M phases were significantly higher in drug-resistant KKU-M139/GEM (19.7 \pm 0.44 and $29.37 \pm 1.74 \%)$ compared with those of parental cells $(12.67 \pm 1.23$ and $11.5 \pm 0.40 \%)(\mathrm{p}<0.01$, Fig. 3A). In KKU-M214/GEM cells, the cells in $\mathrm{G} 2 / \mathrm{M}$ phase $(20.53 \pm 3.95 \%)$ was significantly higher than that $(13.13 \pm 1.01 \%)$ in KKU-M214 cells, but the proportions of the cells in G0/G1 in KKU-M139/GEM and KKU-M214/GEM cells $(43.33 \pm 2.87$ and $47.60 \pm 4.87 \%)$ were significantly lower than those of KKU-M139 and KKU-M214 cells $(68.60 \pm 5.89$ and $63.23 \pm 1.16 \%)(p<0.01$, Fig. 3A).

Downregulation of $G 2 / M$ phase-regulated proteins in gemcitabine-resistant CCA cell lines. Western blot analyses showed that the protein expression of cyclin B1, cyclin-dependent kinase 1 (Cdk1), p53 and p21 was significantly lower in gemcitabine-resistant cells compared to the parental cells ( $<<0.01$, Fig. 3B and C), suggesting the possible role of cyclin B1, Cdk1, p53 and p21 proteins in causing G2/M phase cell cycle arrest in the drug resitant cell lines.

Enhancement of cell adhesion in gemcitabine-resistant CCA cell lines. The ability to adhere to basement membrane is an important characteristic of cancer metastasis. In the cell adhesion assay, the numbers of drug-resistant KKU-M139/GEM and KKU-M214/GEM cells adhered to Matrigel was, respectively, 2.10- and 1.72-fold higher than that of their parental cell lines (p<0.01, Fig. 4).

Apoptotic evasion in gemcitabine-resistant CCA cell lines. Apoptosis induction in parental and gemcitabine-resistant CCA cell lines after treatment with gemcitabine was evaluated using Annexin V-FITC/PI staining. The percentage of apoptotic cells in KKU-M139/GEM cells after $9 \mu \mathrm{M}$ gemcitabine treatment was 0.45 -fold lower than that in parental KKU-M139 cells
( $<<0.001$, Fig. 5A and B). Similarly, the percentage of apoptotic cells in KKU-M214/GEM cells after $16 \mu \mathrm{M}$ gemcitabine treatment was 0.39 -fold lower than that in KKU-M214 cells $(\mathrm{p}<0.001$, Fig. 5A and B). These results indicate apoptotic evasion in KKU-M139/GEM and KKU-M214/GEM.

Aberration of apoptotic regulation in gemcitabine-resistant $C C A$ cell lines. To gain insight into the possible mechanisms of apoptotic evasion in drug-resistant cells, the apoptotic regulated protein expressions of both intrinsic and extrinsic pathways were determined using western blot analyses. In the intrinsic pathway, p53 (Fig. 3B and C) and Bax were downregulated, while Bcl-2 was upregulated in both KKU-M139/GEM and KKU-M214/GEM compared with the parental cells $(\mathrm{p}<0.05$, Fig. 5C and D). In the extrinsic pathway, the FADD protein expression was not different between the parental and gemcitabine-resistant cells. Interestingly, Fas was downregulated in KKU-M214/GEM $(\mathrm{p}<0.001)$ but not in KKU-M139/GEM cells (Fig. 5C and D). These results suggest that KKU-M214/GEM evades apoptosis via both intrinsic and extrinsic pathways, whereas KKU-M139/GEM evades apoptosis through an intrinsic pathway.

Enhancement of migration and invasion in gemcitabineresistant CCA cell lines. The ability of CCA cells to migrate and invade the basement membrane and surrounding tissues is an important characteristics of cancer metastasis. These properties of gemcitabine-resistant cell lines and their parental cell lines were determined using a Boyden chamber assay system. Using the Transwell system, the number of migrated cells of KKU-M139/GEM was 1.89-fold higher than that of the parental cells, whereas the KKU-M214/GEM was 1.98-fold higher than those of parental cells ( $p<0.05$, Fig. 6B). Using the Matrigel invasion assay, the number of invaded cells of KKU-M139/GEM and KKU-M214/GEM were 1.82-fold and 1.72 -fold higher than that in the respective parental cells $(\mathrm{p}<0.05$, Fig. 6D).

Increased MMP-9 and uPA activities in gemcitabine-resistant CCA cell lines. The proteolytic activity of MMP-9 of the parental and gemcitabine-resistant cell lines were measured by gelatin zymography. The MMP-9 activity in KKU-M139/GEM and KKU-M214/GEM was 1.55- and 1.21-fold higher than that in the parental cells ( $p<0.05$, Fig. 7A and B). Using western blot 
Untreated cells Treated cells

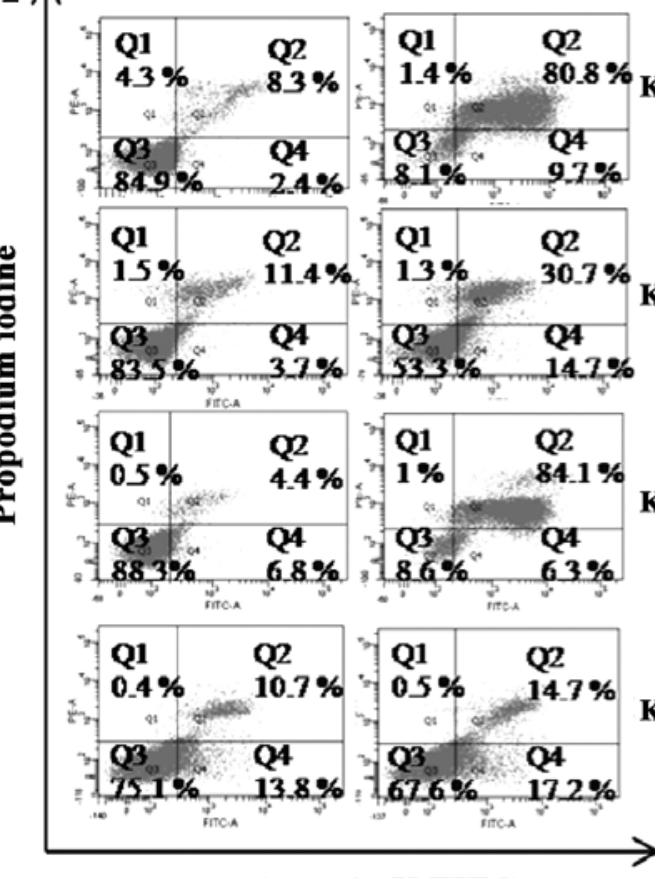

Annexin V-FITC
B

KKU-M139

KKU-M139/GEM

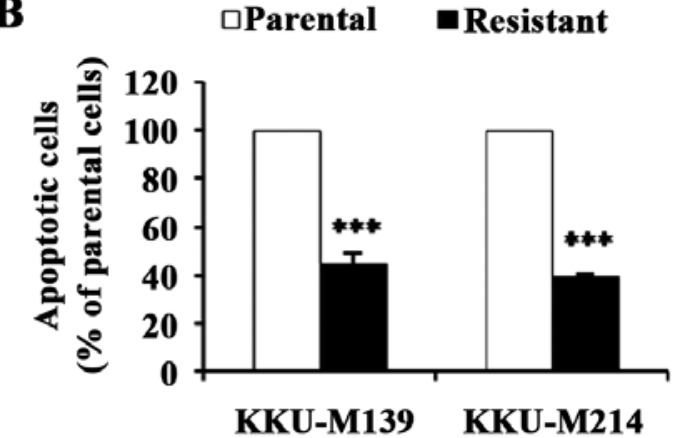

KKU-M214

\section{C}<smiles></smiles>

Bax

KKU-M214/GEM

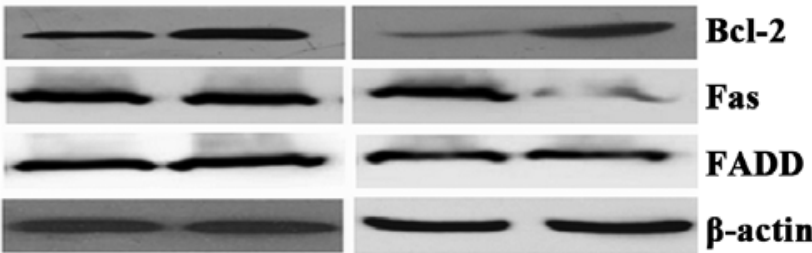

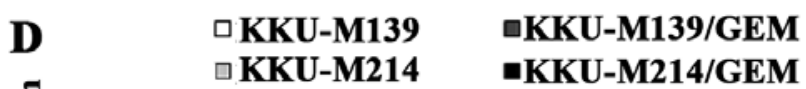

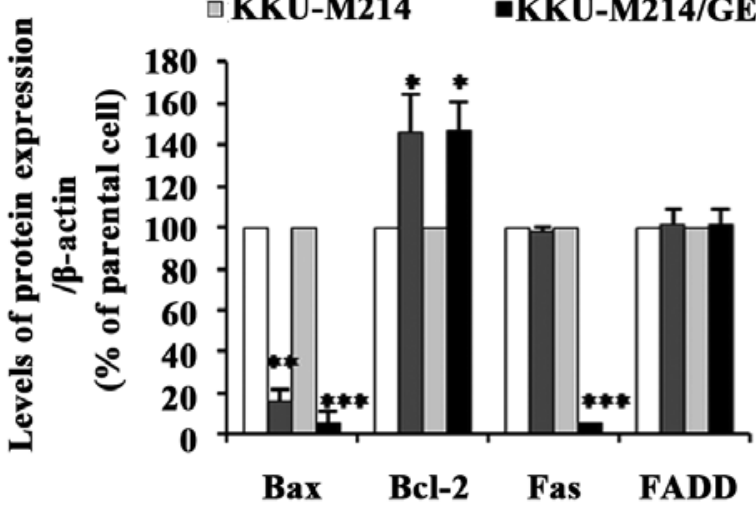

Figure 5. Apoptosis induction was decreased in KKU-M139/GEM and KKU-M214/GEM cells compared with their parental cells. KKU-M139 and KKU-M139/GEM were treated with $9 \mu$ M gemcitabine, whereas KKU-M214 and KKU-M214/GEM were treated with $16 \mu$ M gemcitabine. (A) Apoptotic cells in gemcitabine-treated parental and gemcitabine-resistant cells were determined by Annexin V-FITC/PI staining visualized: viable and non-apoptotic cells (Q3), early apoptotic cells (Q4), late apoptotic cells (Q2) and necrotic cells (Q1). (B) Percentages of apoptotic cells (Q2+Q4) in KKU-M139/GEM and KKU-M214/GEM were significantly lower than KKU-M139 and KKU-M214 cells. (C) Western blot analysis showed apoptosis regulated protein expression levels. Bax expression was decreased while Bcl-2 expression was increased in KKU-M139/GEM and KKU-M214/GEM compared with their parental cells. Fas expression was decreased in KKU-M214/GEM but was not changed in KKU-M139/GEM. (D) The band intensity of the proteins was quantitated by densitometry and normalized to $\beta$-actin. Data are expressed as mean $\pm \mathrm{SD}$ of three independent experiments. Statistical analyses of parental and gemcitabine-resistant cells were performed using Student t-test, ${ }^{*} \mathrm{p}<0.05,{ }^{* *} \mathrm{p}<0.01,{ }^{* * *} \mathrm{p}<0.001$ indicate a significant difference.

analyses, MMP-9 protein expression in KKU-M139/GEM and KKU-M214/GEM was 2.54- and 1.39-fold higher, respectively, than that in the parental cells $(\mathrm{p}<0.01$, Fig. $7 \mathrm{C}$ and D). These results show that an increased enzymatic activity of MMP-9 was due to increased protein expression. The uPA activity in KKU-M139/GEM and KKU-M214/GEM is, respectively, 2.17-fold and 1.81-fold higher than that of the parental cells ( $\mathrm{p}<0.01$, Fig. 7E and F), as determined by casein-plasminogen zymography. These findings suggest that higher activities of MMP-9 and uPA may play a role in higher migration and inva- sion capacities in KKU-M139/GEM and KKU-M214/GEM compared to the parental cells.

PKC signaling pathway plays an important role in apoptosis evasion, cell adhesion, migration and invasion. Cell lysates from the parental and gemcitabine-resistant cell lines were analyzed for protein expression by western blot analyses. Protein levels of all PKC fractions (cytosolic and membrane), FAK and p-FAK were significantly higher in KKU-M139/GEM and KKU-M214/GEM cells compared to those in the respec- 


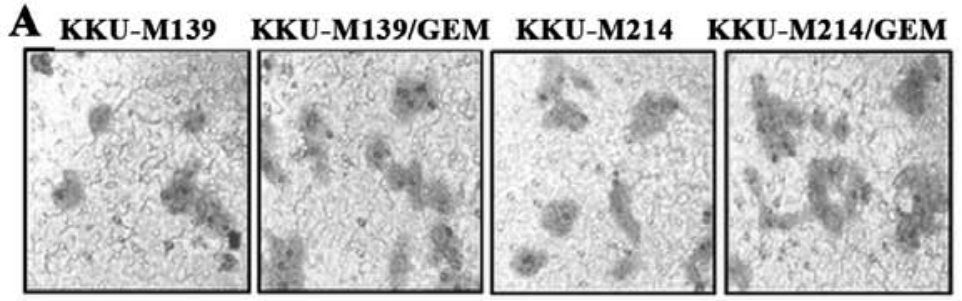

C KKU-M139 KKU-M139/GEM KKU-M214 KKU-M214/GEM

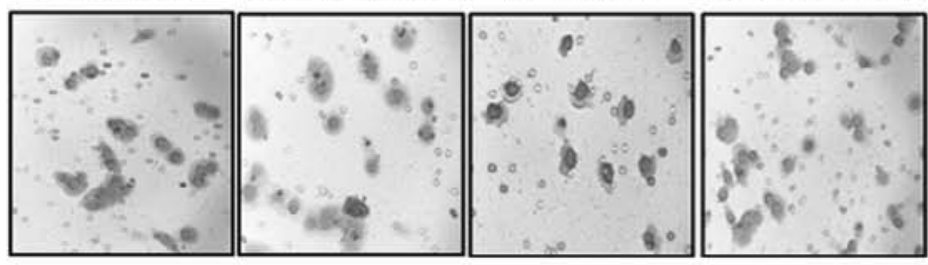

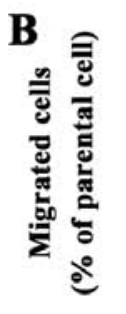

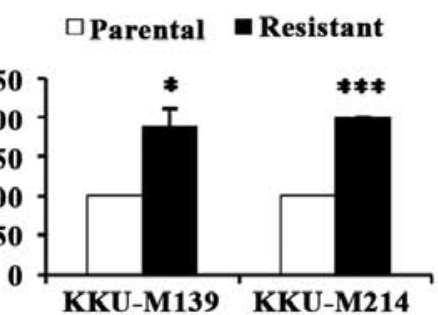

D

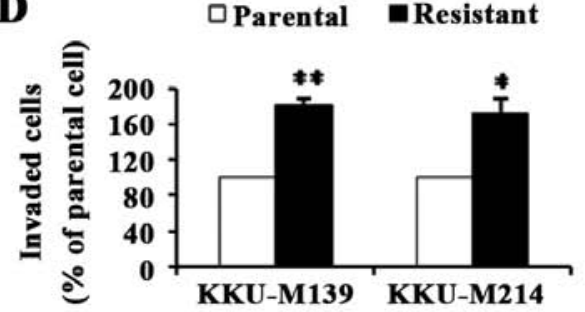

Figure 6. Migration and invasion capacities were higher in KKU-M139/GEM and KKU-M214/GEM compared with their parental cells. (A) Representative images of SRB-stained migrated cells determined by migration assay using the modified Boyden chamber assay (x200). (B) Percentage (\%) of cell migration compared to parental cells. (C) Representative images of SRB-stained invaded cells determined by invasion assay using the modified Boyden chamber assay (x200). (D) Percentage (\%) of cell invasion compared to parental cell. The experiments were performed in triplicate of two independent experiments. All data are expressed as mean \pm SD. Statistical analyses of parental and gemcitabine-resistant cells were performed using Student's t-test, ${ }^{*} \mathrm{p}<0.05,{ }^{* *} \mathrm{p}<0.01,{ }^{* * *} \mathrm{p}<0.001$ indicate a significant difference.
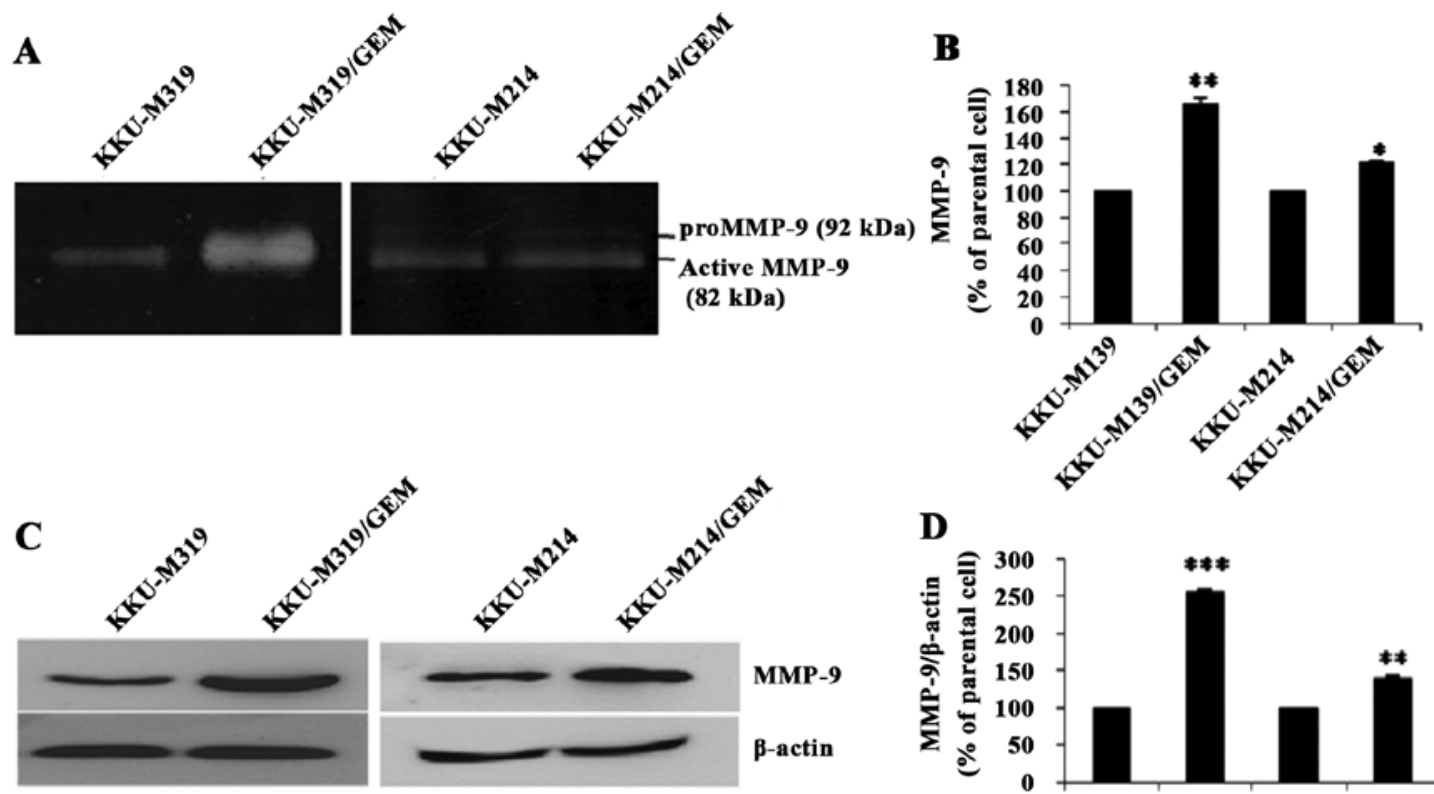

D
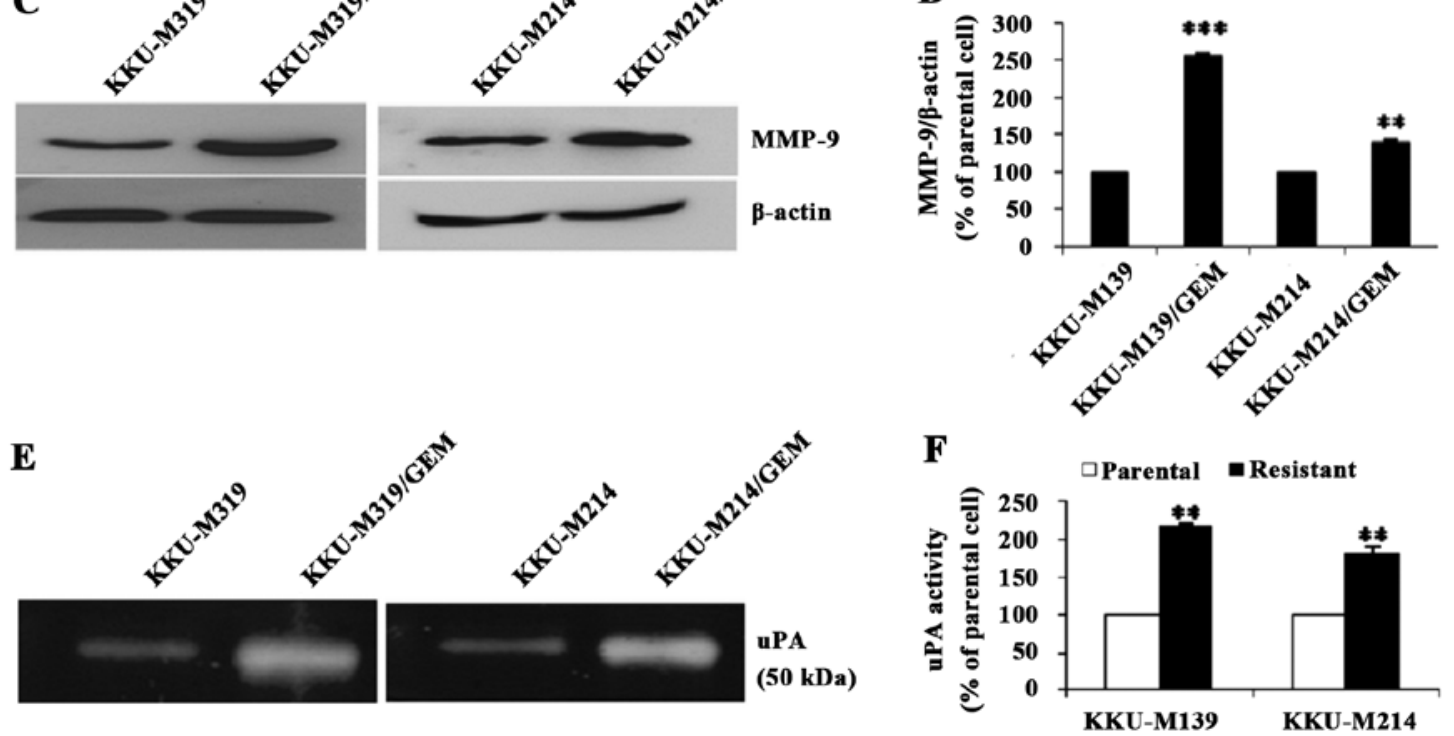

Figure 7. Activities of MMP-9 and uPA and protein expression of MMP-9 were higher in KKU-M139/GEM and KKU-M214/GEM compared with their parental cells. (A) Gelatinolytic activity of MMP-9 in the condition medium was determined by gelatin zymography. (B) The band intensities of the active MMP-9 were quantified by densitometry. (C) Protein expression of MMP-9 was determined by western blot analysis. (D) The band intensity of the MMP-9 was quantitated by densitometry and normalized to $\beta$-actin. (E) uPA activity in the conditioned medium was determined by casein-plasminogen zymography. (F) The band intensity of uPA activity was quantitated by densitometry. Data are expressed as mean \pm SD of three independent experiments. Statistical analyses of parental and gemcitabine-resistant cells were performed using Student's $t$-test, ${ }^{*} \mathrm{p}<0.05,{ }^{* * *} \mathrm{p}<0.01,{ }^{* * * *} \mathrm{p}<0.001$ indicate a significant difference. 
$\mathbf{A}$
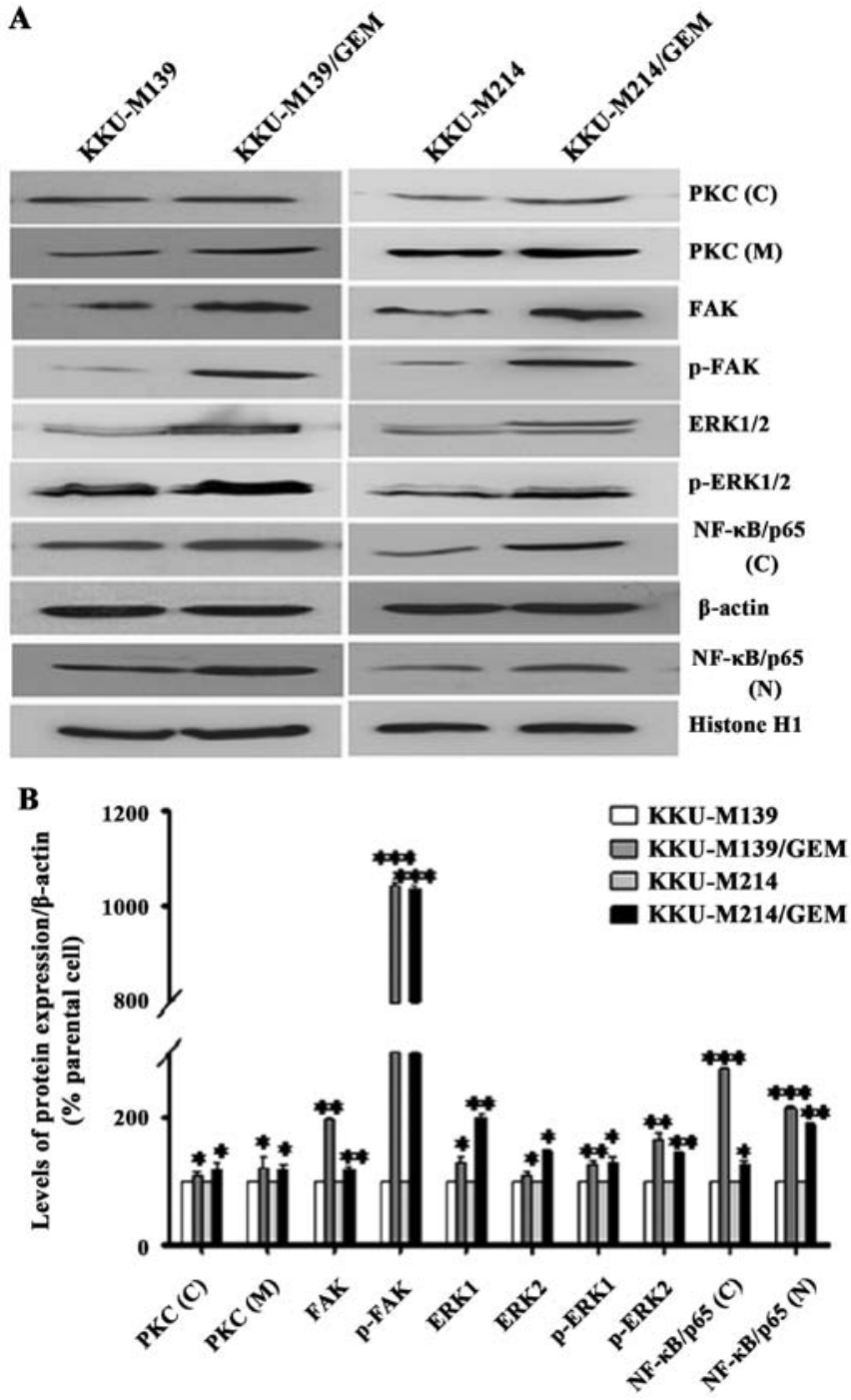

Figure 8. Activation of PKC signaling pathways in KKU-M139/GEM and KKU-M214/GEM. (A) Cell lysates from the parental and gemcitabine-resistant cell lines were analyzed for protein expression by western blot analyses. The protein expression levels of PKC (C, cytosolic), PKC (M, membrane),

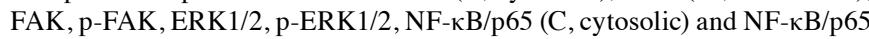
(N, nucleus) were higher in KKU-M139/GEM and KKU-M214/GEM compared with their parental cells. (B) The band intensity of the proteins was quantitated by densitometry and normalized to $\beta$-actin (total cell, cytosolic and membrane lysates) and Histone $\mathrm{H} 1$ (nuclear lysate). Data are expressed as mean \pm SD of three independent experiments. Statistical analyses of parental and gemcitabine-resistant cells were performed using Student's t-test, ${ }^{*} \mathrm{p}<0.05,{ }^{* *} \mathrm{p}<0.01,{ }^{* * *} \mathrm{p}<0.001$ indicate a significant difference.

tive parental cells $(\mathrm{p}<0.05$, Fig. 8$)$. In the PKC downstream signaling pathway, protein levels of ERK1/2, p-ERK1/2 and fractions of NF- $\mathrm{kB} / \mathrm{p} 65$ (cytosolic and nuclear) were significantly higher in KKU-M139/GEM and KKU-M214/GEM cells compared to those of the respective parental cells ( $<<0.05$, Fig. 8). These results suggest that higher expression of PKC membrane fraction, p-FAK, p-ERK1/2 and NF- $\kappa B$ nuclear fraction may play role in higher protein level of $\mathrm{Bcl}-2$, MMP-9 and uPA in KKU-M139/GEM and KKU-M214/GEM cells compared to the parental cells. These findings suggest the signaling pathways involved in apoptosis evasion, cell adhesion, migration and invasion of gemcitabine-resistant CCA cell lines as proposed in Fig. 9.

\section{Discussion}

In this study, we successfully established highly gemcitabineresistant CCA cell lines, from the respective parental CCA cell lines, KKU-M139 and KKU-M214. The $\mathrm{IC}_{50}$ values of KKU-M139/GEM and KKU-M214/GEM were 10.16 and $28.04 \mu \mathrm{M}$, respectively, which was far higher than those of previously reported gemcitabine-resistant cell lines, HuCCT1 and YSCCC, for which $\mathrm{IC}_{50}$ was 0.26 and $0.04 \mu \mathrm{M}$, respectively (17). The gemcitabine-resistance remained stable after continuous culture in drug-free medium for 2 months, and was also stable even following storage at $-80^{\circ} \mathrm{C}$ for 3 months.

Acquired gemcitabine resistance involved the alteration of gemcitabine transporter and disruption of gemcitabine metabolism to convert its active form. In our results, $R R M 1$ was upregulated and $h E N T 1$ and $d C K$ were downregulated, suggesting that $h E N T 1, d C K$ and $R R M 1$ play an important role in gemcitabine resistance. In non-small cell lung cancer cells, expression of $h E N T 1$ and $d C K$ was decreased whereas $R R M I$ was increased in association with acquired gemcitabineresistance $(8,11)$.

The importance of ATP-binding cassette (ABC) transporters in mediating drug efflux is well documented (26). MRP expression was associated with decreased intracellular accumulation of various chemotherapeutic agents (27). Our results demonstrated that both of the gemcitabine-resistant cells overexpressed MRP1 protein compared to their parental cells. Overexpression of MRP1-3 has been reported in CCA $(18,28)$. Thus, upregulation of MRP1 led to an increase of drug efflux resulted in multidrug resistance. Even though these anticancer drugs are different in their structure and anticancer mechanisms, the disruption of drug transporter function contribute to an acquired MDR in CCA cells. Hence, KKU-M139/GEM and KKU-M214/GEM showed cross-resistance to several anticancer drugs simultaneously, for example; 5-FU, doxorubicin and paclitaxel. 5-FU and gemcitabine share similar molecular structure, mechanisms of action and metabolic characteristics (15). This might explain why gemcitabine-resistant CCA cells can become cross-resistant to 5-FU. Paclitaxel is primarily an M-phase-specific drug that stabilize microtubules, resulting in an arrest of the cell cycle in M-phase and apoptosis (29). The G2/M arrest of gemcitabine-resistant CCA cells prevents cells entering M-phase where paclitaxel is mostly active and gain an advantage for acquired paclitaxel resistance. Doxorubicin can only target cell cycling and proliferation. Therefore, doxorubicin may lose anticancer activity if the gemcitabineresistant CCA cells are prevented from entering cell cycle by G2/M-phase arrest. The association of decreased expression of cyclin B1 with doxorubicin resistance was reported in breast cancer cells (30).

Extension of the population doubling time in chemoresistance has been reported in a variety of cancer cells $(5,31)$. The prolonged proliferating time of the gemcitabine-resistant CCA cell lines reported here seems to have resulted from cell cycle arrest at G2/M phase because of decreased cyclin B1 and Cdk1 expression. Similar findings have been reported in adriamycin-resistant CCA cell line (QBC939/ADM) (32). Transition from $\mathrm{G} 2$ to $\mathrm{M}$ phase of the cell cycle is regulated by the Cdk1/cyclin B1 complex and CDKIs including p21 and p27 (33). P53 is a key tumor suppressor protein which is known 


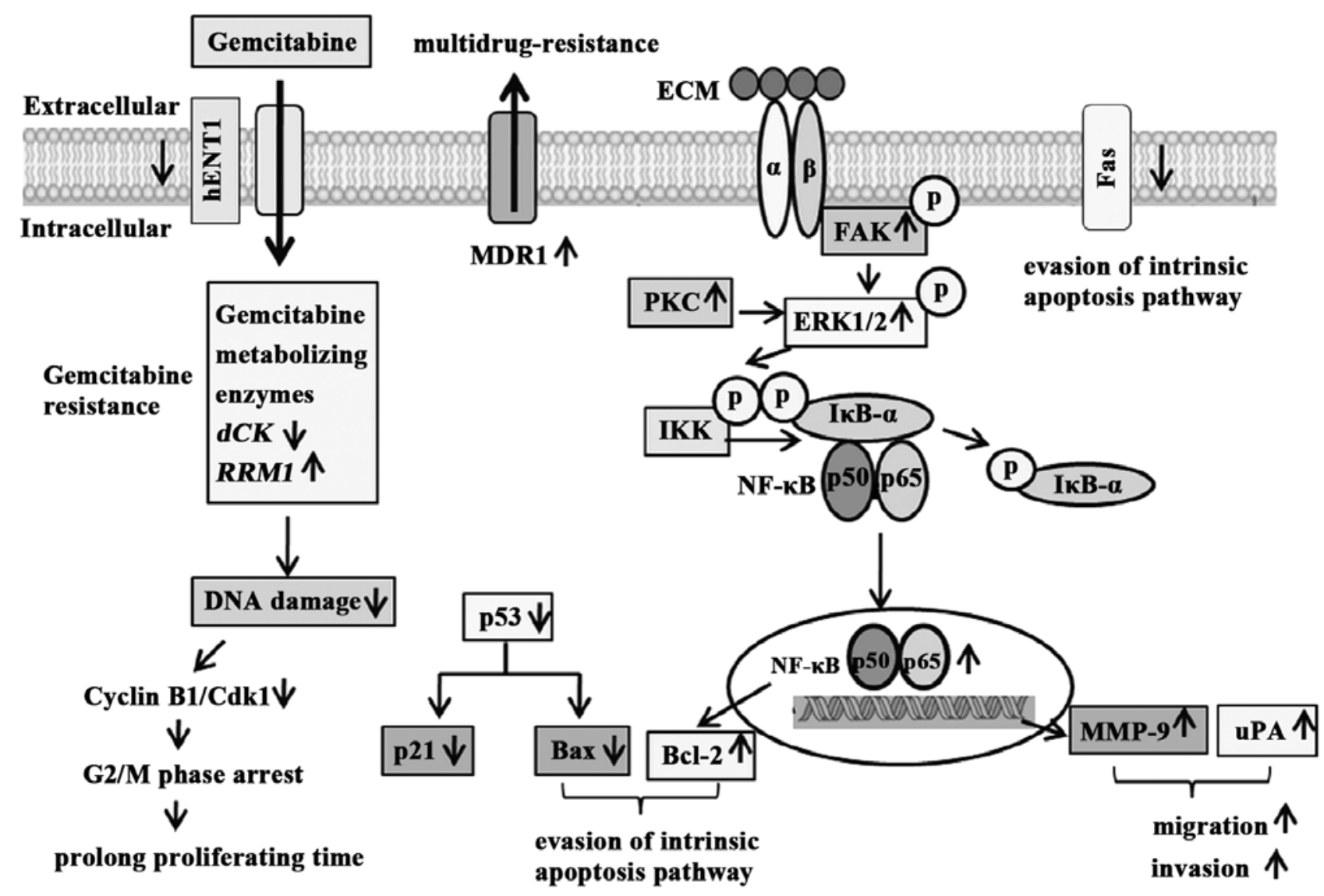

Figure 9. A possible mechanism by which CCA mediates gemcitabine resistance and invasiveness.

as a transcriptional regulator of p21 and Bax (34). Our results also suggested the downregulation of p21 via decreased p53. Loss of p21 expression after chemotherapy was observed in human resistant tumor models harboring wild-type p53 (35). Taken together, the altered cell cycle profile of gemcitabineresistant CCA cell lines may provide some advantages from killing by anticancer drugs. G2 arrest allows damage repair and eventual resumption of the cell cycle progression, preventing cells from anticancer activity of chemotherapeutic drugs.

Evasion of apoptosis via intrinsic and extrinsic pathway has been evident as the usual mechanism for chemoresistance (13). In this study, after treatment with gemcitabine, the percentage of apoptotic cells in both of the gemcitabineresistant CCA cells were significantly decreased compared to their parental cells. In the mitochondrial (intrinsic) apoptosis pathway, the Bcl-2 family proteins including anti-apoptotic proteins (i.e., Bcl-2, Mcl-1 and Bcl-XL) and pro-apoptotic proteins (i.e., Bax) played an important role (14). An increase in the ratio of anti- to pro-apoptotic $\mathrm{Bcl}-2$ proteins has been detected in various cancers and has been correlated to tumor cell survival and apoptosis resistance (14). Acquired resistance of pancreatic cancer cell line, Capan-1, against gemcitabine was associated with upregulation of the anti-apoptotic genes bcl-XL and mcl-1 and a higher ratio of Bcl-2/Bax expression (15). In this study, downregulation of p53 expression may cause decreased Bax protein expression which is the target gene product induced by $\mathrm{p} 53$. Our present data indicate that resistance to chemotherapeutic drugs of two CCA cell lines is at least partly mediated via the increase of $\mathrm{Bcl}-2$ protein expression and decrease of p53 and Bax protein expression. These changes lead to increased $\mathrm{Bcl}-2 / \mathrm{Bax}$ ratio and evasion of the intrinsic apoptosis pathway.

In the death receptor (extrinsic) apoptosis pathway, ligation of death receptors to the tumor necrosis factor (TNF) receptor super-family (i.e., CD95 or Fas) by the corresponding ligands (i.e., CD95 ligand or Fas ligand) leads to the recruitment of proteins such as Fas-associated death domain (FADD) and caspase- 8 and subsequently activation of caspase- 8 , caspase- 3 leading to apoptotic cell death (36). In this study, Fas expression was significantly decreased in KKU-M214/GEM but was unaltered in KKU-M139/GEM compared with their parental cells. In contrast, the FADD expression was not changed in either of the gemcitabine-resistant CCA cells. These results indicate that decreased expression of Fas in KKU-M214/GEM may prevent the transmission of the death signal from the cell surface to intracellular signaling cascades leading to evasion of the extrinsic apoptosis pathway. Decreased expression of Fas has been reported in chemotherapeutic drug-resistant human renal cell carcinoma (37). It is interesting to note that KKU-M214/GEM may evade apoptosis through both intrinsic and extrinsic pathways, whereas, KKU-M139/GEM may evade apoptosis only through the intrinsic pathway. These results may explain the higher $\mathrm{IC}_{50}$ values of gemcitabine in KKU-M214/GEM $(28.04 \pm 0.68 \mu \mathrm{M})$ than in KKU-M139/GEM $(10.16 \pm 0.10 \mu \mathrm{M})$. Additionally, decrease of Fas expression 
would also allow cells to evade immune responses mediated by both $\mathrm{T}$ and NK cells.

Invasion of cancer cells into basement membranes is a critical step in metastasis. The key markers that are involved in degradation of the ECM are the serine protease (plasmin), urokinase plasminogen activator (uPA) system, cysteine protease (cathepsin B and L) and matrix metalloproteinases (MMPs) (38). In our study, the established resistant cell lines demonstrated the relationship between drug resistance and cancer invasion. Both KKU-M139/GEM and KKU-M214/GEM exhibited an aggressive phenotype, i.e., higher migration and invasion capabilities with higher MMP-9 and uPA activities, similar to those in various cancer cell lines reported previously $(39,40)$. The exposure of the human nasal carcinoma cell line RPMI-2650 to melphalan, an alkylating agent, resulted in not only an MDR phenotype but also enhancement of cell invasion in vitro. However, paclitaxel (Taxol) exposure promoted MDR without altered cell invasiveness (39). Osmak et al reported increased cathepsin D, uPA and plasminogen activator inhibitor-1 (PAI-1) in a drug-resistant cervical and laryngeal cell line, although they did not investigate the invasive/metastatic potential of these cells (40).

Environmental-mediated drug resistance (EMDR) is thought to be triggered by the adhesion of integrins from tumor cells to stromal fibroblast or to components of the surrounding extracellular matrix (ECM) (41). The signaling could be due to degradation of apoptotic proteins or enhanced stability or altered subcellular distribution of anti-apoptotic proteins and cell cycle regulators $(42,43)$. During adhesion, ligation of integrin with ECM ligands trigger PKC translocation from cytosol to the intracellular membrane (44). PKC is a family of serine/threonine kinases associated with the regulation of cell cycle progression either during the G1/S or $\mathrm{G} 2 / \mathrm{M}$ transition, cell adhesion, migration, invasion and drug resistance (45). Elevated levels of PKC and its downstream, FAK, have been shown in various cancer cells $(44,45)$. FAK is a cytoplasmic tyrosine kinase that plays an important role in integrin-mediated signaling. It is the key mediator of several signaling pathways, especially ERK1/2, which is in the mitogen-activated protein kinases (MAPK) pathway (46). ERK1/2 also regulates transcription factor $N F-\kappa B$ indirectly by phosphorylating inhibitor of NF- $\kappa \mathrm{B}$ kinase- $\alpha$ (IKK- $\alpha$ ), IKK- $\alpha$ subsequently phosphorylates inhibitor of NF- $\mathrm{BB}(\mathrm{I} \kappa \mathrm{B})$, leading to ubiquitination and degradation of I $\mathrm{KB}-\alpha$. This promotes the translocation of $\mathrm{NF}-\kappa \mathrm{B}$ from the cytoplasm to the nucleus driving the transcription of its target genes $(47,48)$. Our results confirm previous finding that all fractions of PKC expression, FAK phosphorylation, ERK1/2 phosphorylation, two fractions of $\mathrm{NF}-\kappa \mathrm{B} / \mathrm{p} 65$ expression were increased in both gemcitabine-resistant CCA cells suggesting the involvement of the PKC and MAPK signaling pathways. Additionally, ERK1/2 signaling is responsible for resistance to gemcitabine in other CCA cells (49). Also in CCA $\left(\mathrm{SCK}^{\mathrm{R}}\right)$ cells, the activation of AKT and ERK1/2 signaling induced by cisplatin is likely to be the mechanism of cisplatin resistance, while the activation of ERK1/2 signaling is involved in 5-FU and gemcitabine resistance (50). The possible signaling pathways involved in the mediation of gemcitabine resistance of CCA are shown in Fig. 9.
In conclusion, the establishment of CCA cell lines highly resistant to gemcitabine was achieved using stepwise long-term exposure to the ascending series of gemcitabine. The established cell lines harbor multidrug resistance and invasiveness. The mechanism of enhanced drug resistance may include MRP1 expression, activation of the PKC signaling pathway, $\mathrm{NF}-\kappa \mathrm{B}$ activation and its downstream targets resulting in prolongation of proliferation time, evasion from apoptosis, and an increase of cancer invasiveness. An increased understanding of relationship between drug resistance and cancer cell invasiveness will ultimately lead to a consideration of means by which induction of the aggressive phenotype should be avoided. Finally, molecular targets for circumvention of multidrug resistance and invasion are revealed for possible targeted therapy for CCA.

\section{Acknowledgements}

This study was supported in part by grants from the Center of Excellence for Innovation in Chemistry, Commission on Higher Education (grant no. 48-03-3-00-144), Khon Kaen University (grant nos. 563903, 573302, 582702) Research Fund, and Khon Kaen University under the Incubation Researcher Project, Khon Kaen University, Thailand. The authors sincerely thank Professor Yukifumi Nawa, invited Professor/Consultant, KKU, for reviewing the manuscript.

\section{References}

1. Khan SA, Taylor-Robinson SD, Toledano MB, Beck A, Elliott $P$ and Thomas HC: Changing international trends in mortality rates for liver, biliary and pancreatic tumours. J Hepatol 37: 806-813, 2002.

2. Valverde A, Bonhomme N, Farges O, Sauvanet A, Flejou JF and Belghiti J: Resection of intrahepatic cholangiocarcinoma: A Western experience. J Hepatobiliary Pancreat Surg 6: 122-127, 1999.

3. Skipworth JR, Olde Damink SW, Imber C, Bridgewater J, Pereira SP and Malagó M: Review article: Surgical, neo-adjuvant and adjuvant management strategies in biliary tract cancer. Aliment Pharmacol Ther 34: 1063-1078, 2011.

4. Macias R: Cholangiocarcinoma: Biology, clinical management, and phamacological perspectives. ISRN Hematol 2014: 1-13, 2014.

5. Chen SY, Hu SS, Dong Q, Cai JX, Zhang WP, Sun JY, Wang TT, Xie J, He HR, Xing JF, et al: Establishment of paclitaxel-resistant breast cancer cell line and nude mice models, and underlying multidrug resistance mechanisms in vitro and in vivo. Asian Pac J Cancer Prev 14: 6135-6140, 2013.

6. Voutsadakis IA: Molecular predictors of gemcitabine response in pancreatic cancer. World J Gastrointest Oncol 3: 153-164, 2011.

7. Hertel LW, Boder GB, Kroin JS, Rinzel SM, Poore GA, Todd GC and Grindey GB: Evaluation of the antitumor activity of gemcitabine (2',2'-difluoro-2'-deoxycytidine). Cancer Res 50: 4417-4422, 1990.

8. Achiwa H, Oguri T, Sato S, Maeda H, Niimi T and Ueda R: Determinants of sensitivity and resistance to gemcitabine: The roles of human equilibrative nucleoside transporter 1 and deoxycytidine kinase in non-small cell lung cancer. Cancer Sci 95: 753-757, 2004.

9. Plunkett W, Huang P, Xu YZ, Heinemann V, Grunewald R and Gandhi V: Gemcitabine: Metabolism, mechanisms of action, and self-potentiation. Semin Oncol 22 (Suppl 11): S3-S10, 1995.

10. Goan YG, Zhou B, Hu E, Mi S and Yen Y: Overexpression of ribonucleotide reductase as a mechanism of resistance to 2,2-difluorodeoxycytidine in the human KB cancer cell line. Cancer Res 59: 4204-4207, 1999.

11. Davidson JD, Ma L, Flagella M, Geeganage S, Gelbert LM and Slapak CA: An increase in the expression of ribonucleotide reductase large subunit 1 is associated with gemcitabine resistance in non-small cell lung cancer cell lines. Cancer Res 64: 3761-3766, 2004. 
12. Meli M, Tolomeo M, D'Alessandro N, Grimaudo S, Notarbartolo M, Papoff G, Ruberti G, Rausa L and Dusonchet L: Resistance to gemcitabine in a lymphoma cell line resistant to Fas-mediated apoptosis. Anticancer Res 24B: 851-857, 2004.

13. Akada M, Crnogorac-Jurcevic T, Lattimore S, Mahon P, Lopes R, Sunamura M, Matsuno S and Lemoine NR: Intrinsic chemoresistance to gemcitabine is associated with decreased expression of BNIP3 in pancreatic cancer. Clin Cancer Res 11: 3094-3101, 2005.

14. Fulda S: Tumor resistance to apoptosis. Int J Cancer 124: 511-515, 2009.

15. Shi X, Liu S, Kleeff J, Friess H and Büchler MW: Acquired resistance of pancreatic cancer cells towards 5-Fluorouracil and gemcitabine is associated with altered expression of apoptosisregulating genes. Oncology 62: 354-362, 2002.

16. Bergman AM, Pinedo HM and Peters GJ: Determinants of resistance to 2',2'-difluorodeoxycytidine (gemcitabine). Drug Resist Updat 5: 19-33, 2002.

17. Sato J, Kimura T, Saito T, Anazawa T, Kenjo A, Sato Y, Tsuchiya $\mathrm{T}$ and Gotoh $\mathrm{M}$ : Gene expression analysis for predicting gemcitabine resistance in human cholangiocarcinoma. J Hepatobiliary Pancreat Sci 18: 700-711, 2011

18. Tepsiri N, Chaturat L, Sripa B, Namwat W, Wongkham S, Bhudhisawasdi V and Tassaneeyakul W: Drug sensitivity and drug resistance profiles of human intrahepatic cholangiocarcinoma cell lines. World J Gastroenterol 11: 2748-2753, 2005.

19. Namwat N, Amimanan P, Loilome W, Jearanaikoon P, Sripa B, Bhudhisawasdi V and Tassaneeyakul W: Characterization of 5-fluorouracil-resistant cholangiocarcinoma cell lines. Chemotherapy 54: 343-351, 2008.

20. Thanasai J, Limpaiboon T, Jearanaikoon P, Sripa B, Pairojkul C, Tantimavanich S and Miwa M: Effects of thymidine phosphorylase on tumor aggressiveness and 5-fluorouracil sensitivity in cholangiocarcinoma. World J Gastroenterol 16: 1631-1638, 2010.

21. Skehan P, Storeng R, Scudiero D, Monks A, McMahon J, Vistica D, Warren JT, Bokesch H, Kenney S and Boyd MR: New colorimetric cytotoxicity assay for anticancer-drug screening. J Natl Cancer Inst 82: 1107-1112, 1990.

22. De Angelis PM, Kravik KL, Tunheim SH, Haug T and Reichelt WH: Comparison of gene expression in HCT116 treatment derivatives generated by two different 5 -fluorouracil exposure protocols. Mol Cancer 3: 11, 2004.

23. Yodkeeree S, Chaiwangyen W, Garbisa S and Limtrakul P. Curcumin, demethoxycurcumin and bisdemethoxycurcumin differentially inhibit cancer cell invasion through the downregulation of MMPs and uPA. J Nutr Biochem 20: 87-95, 2009.

24. Zhang S, Furugawa T, Takahashi $\mathrm{H}$, et al: Analysis of gene expression in gemcitabine-resistant cells derived from human pancreatic cancer cell. International Conference on Human Health and Biomedical Engineering pp182-185, 2011.

25. Gerard CJ, Olsson K, Ramanathan R, Reading C and Hanania EG: Improved quantitation of minimal residual disease in multiple myeloma using real-time polymerase chain reaction and plasmidDNA complementarity determining region III standards. Cancer Res 58: 3957-3964, 1998

26. Modok S, Mellor HR and Callaghan R: Modulation of multidrug resistance efflux pump activity to overcome chemoresistance in cancer. Curr Opin Pharmacol 6: 350-354, 2006.

27. Zaman GJ, Flens MJ, van Leusden MR, de Haas M, Mülder HS Lankelma J, Pinedo HM, Scheper RJ, Baas F and Broxterman HJ: The human multidrug resistance-associated protein MRP is a plasma membrane drug-efflux pump. Proc Natl Acad Sci USA 91: 8822-8826, 1994.

28. Courtois A, Payen L, Lagadic D, Guillouzo A and Fardel O: Evidence for a multidrug resistance-associated protein 1 (MRP1)-related transport system in cultured rat liver biliary epithelial cells. Life Sci 64: 763-774, 1999.

29. Shah MA and Schwartz GK: Cell cycle-mediated drug resistance: An emerging concept in cancer therapy. Clin Cancer Res 7: 2168-2181, 2001 .

30. Smith L, Watson MB, O'Kane SL, Drew PJ, Lind MJ and Cawkwell L: The analysis of doxorubicin resistance in human breast cancer cells using antibody microarrays. Mol Cancer Ther 5: 2115-2120, 2006
31. Guo X, Goessl E, Jin G, Collie-Duguid ES, Cassidy J, Wang W and O'Brien V: Cell cycle perturbation and acquired 5-fluorouracil chemoresistance. Anticancer Res 28A: 9-14, 2008.

32. Liu ZH, He YP, Zhou Y, Zhang P and Qin H: Establishment and identification of the human multi-drug-resistant cholangiocarcinoma cell line QBC939/ADM. Mol Biol Rep 38: 3075-3082, 2011

33. Wu ZZ, Chien CM, Yang SH, Lin YH, Hu XW, Lu YJ, Wu MJ and Lin SR: Induction of G2/M phase arrest and apoptosis by a novel enediyne derivative, THDA, in chronic myeloid leukemia (K562) cells. Mol Cell Biochem 292: 99-105, 2006.

34. Reinke V and Lozano G: Differential activation of p53 targets in cells treated with ultraviolet radiation that undergo both apoptosis and growth arrest. Radiat Res 148: 115-122, 1997.

35. Siddik ZH, Mims B, Lozano G and Thai G: Independent pathways of p53 induction by cisplatin and X-rays in a cisplatin-resistant ovarian tumor cell line. Cancer Res 58: 698-703, 1998.

36. Strasser A, Puthalakath H, O'Reilly LA and Bouillet P: What do we know about the mechanisms of elimination of autoreactive $T$ and $\mathrm{B}$ cells and what challenges remain. Immunol Cell Biol 86: 57-66, 2008.

37. Ramp U, Dejosez M, Mahotka C, Czarnotta B, Kalinski T, Wenzel M, Lorenz I, Müller M, Krammer P, Gabbert HE, et al: Deficient activation of CD95 (APO-1/Fas)-mediated apoptosis: A potential factor of multidrug resistance in human renal cell carcinoma. Br J Cancer 82: 1851-1859, 2000.

38. Liotta LA, Tryggvason K, Garbisa S, Hart I, Foltz CM and Shafie S: Metastatic potential correlates with enzymatic degradation of basement membrane collagen. Nature 284: 67-68, 1980.

39. Liang Y, Meleady P, Cleary I, McDonnell S, Connolly L and Clynes M: Selection with melphalan or paclitaxel (Taxol) yields variants with different patterns of multidrug resistance, integrin expression and in vitro invasiveness. Eur J Cancer 37: 1041-1052, 2001.

40. Liang Y, McDonnell S and Clynes M: Examining the relationship between cancer invasion/metastasis and drug resistance. Curr Cancer Drug Targets 2: 257-277, 2002.

41. Zahreddine $\mathrm{H}$ and Borden KL: Mechanisms and insights into drug resistance in cancer. Front Pharmacol 4: 28, 2013.

42. Hazlehurst LA, Argilagos RF and Dalton WS: Betal integrin mediated adhesion increases Bim protein degradation and contributes to drug resistance in leukaemia cells. Br J Haematol 136: 269-275, 2007.

43. Lwin T, Hazlehurst LA, Dessureault S, Lai R, Bai W, Sotomayor E, Moscinski LC, Dalton WS and Tao J: Cell adhesion induces p27Kip1-associated cell-cycle arrest through down-regulation of the SCFSkp2 ubiquitin ligase pathway in mantle-cell and other non-Hodgkin B-cell lymphomas. Blood 110: 1631-1638, 2007.

44. Goel HL and Dey CS: Role of protein kinase C during insulin mediated skeletal muscle cell spreading. J Muscle Res Cell Motil 23: 269-277, 2002.

45. Kang J: Protein kinase C (PKC) isozymes and cancer. New J Sci 36: 2014, 2014.

46. Liao CH, Sang S, Ho CT and Lin JK: Garcinol modulates tyrosine phosphorylation of FAK and subsequently induces apoptosis through down-regulation of Src, ERK, and Akt survival signaling in human colon cancer cells. J Cell Biochem 96: 155-169, 2005.

47. Perkins ND: The Rel/NF-kappa B family: Friend and foe. Trends Biochem Sci 25: 434-440, 2000.

48. Ghosh S and Karin M: Missing pieces in the NF-kappaB puzzle. Cell 109 (Suppl): S81-S96, 2002.

49. Matsumoto K, Nagahara T, Okano J and Murawaki Y: The growth inhibition of hepatocellular and cholangiocellular carcinoma cells by gemcitabine and the roles of extracellular signal-regulated and checkpoint kinases. Oncol Rep 20: 863-872, 2008.

50. Yoon H, Min JK, Lee JW, Kim DG and Hong HJ: Acquisition of chemoresistance in intrahepatic cholangiocarcinoma cells by activation of AKT and extracellular signal-regulated kinase (ERK)1/2. Biochem Biophys Res Commun 405: 333-337, 2011. 